\title{
19. PEDOGENIC ALTERATION OF BASALTS RECOVERED DURING LEG $144^{1}$
}

\author{
Mary Anne Holmes ${ }^{2}$
}

\begin{abstract}
Basalts erupted to form the atolls and guyots of the Western Pacific have been altered in various ways, ranging from hydrothermal alteration to subaerial weathering by meteoric waters in a tropical environment. Subaerial weathering has been moderate to extreme. Moderate subaerial weathering is expressed by dissolution or replacement of primary minerals (olivine, pyroxenes, plagioclase feldspar) and alteration of glassy or aphanitic matrix to clay minerals, goethite, and hematite. The clay minerals are kaolinite or a brown smectite. Kaolinite concentrations decrease downhole and smectite concentrations increase. Although primary minerals are generally not preserved, primary structures, such as vesicles (generally filled by secondary or tertiary minerals), flow structure, or relict breccia structure, remain evident. Extreme subaerial weathering is expressed by the loss of all primary minerals as well as all traces of primary structures, presumably by plant root and soil infaunal bioturbation, resulting in recognizable soil. Kaolinite, goethite, and hematite have replaced all primary components. Hydrothermal alteration is expressed by the presence of analcime and delicate zonation in vesicles and veins of secondary minerals. The hydrothermal clay in this case is a green smectite; analcime and other zeolites are present.

Soil development has occurred at Sites $871(28.6 \mathrm{~m}$ thick), $873(22.5 \mathrm{~m}), 874(15 \mathrm{~m}), 877(5 \mathrm{~m})$, and possibly $878(9.6 \mathrm{~m})$ and $879(40.2 \mathrm{~m})$. Sites 871 and 873 exhibit the most extreme weathering and pedogenesis, expressed by soil horizonation, loss of parent relict structure, and distinct vertical zonations of mineral and chemical compositions, from kaolinitic at the surface to smectitic at the base. B horizons were identified from these paleosols, and a possible reworked A horizon occurs at Site 871. The relict parent structure is still very evident in the clays at Sites $874,877,878$, and 879 as well as in the deeper parts of Sites 871 and 873. These are interpreted as C horizons. The parent materials-lava flows and epiclastic volcanic deposits-are completely altered to clay: to kaolinite at Site 874 and to kaolinite and smectite at the others. The clays at Site 877 are vertically zoned; they are not vertically zoned at Sites 878 or 879 . The clays at Sites 878 and 879 may have been altered by groundwater, are very deep parts of soil profiles, or else are the products of multiple deposition and pedogenic events.

The depth of soil development and the mineral composition (absence of gibbsite) suggest that at Site 871 on Limalok Guyot, soils developed in upland areas were subjected to annual rainfall of less than $1 \mathrm{~m}$. Relief was at least tens of meters and possibly more. The presence of a drab mottled horizon at Site 873 indicates it formed in a poorly drained, possibly low-lying area on Wodejebato Island. Rainfall here was also insufficient to generate gibbsite. Similar depths of weathering mantles and the degree of soil development that occurs on older land surfaces of the older Hawaiian Islands suggest a duration for weathering and pedogenesis at Site 871 of 1 to perhaps 3 m.y.
\end{abstract}

\section{INTRODUCTION}

Ocean Drilling Program (ODP) Leg 144 targeted drowned carbonate platforms on seamounts in the western Pacific (see site map preceding the title page) in an effort to determine eustatic sea-level changes from the Cretaceous through the Cenozoic, as well as the geographic and volcanic origin of the guyots. The timing of emplacement and the subsequent uplift and subsidence of the guyots form a key part of this objective, and consequently basalt was sampled whenever possible. The upper part of the edifice-forming basalt was altered at each site. In the more deeply recovered basalt, the alteration was relatively mild, resulting in replacement of glassy matrix by clay, alteration of olivine to iddingsite, and filling in of veins and vugs with secondary minerals, principally clays and zeolites (Premoli Silva, Haggerty, Rack, et al., 1993). At Sites 871 (Limalok Guyot), 873, 874, 877 (Wodejebato Guyot), 878 (MIT Guyot), and 879 (Seiko Guyot), however, thick weathered horizons were recovered beneath marine deposits and above fresher basalt. The extent of soil development represented by these weathering horizons can provide information on the terrestrial environment into which the basalts were erupted, such as the amount of rainfall and emplacement in the landscape (i.e., altitude). Basalt is an especially useful parent material for climate studies of paleosols, as weathering produces a suite of minerals that becomes increasingly enriched in aluminum and depleted in magne-

'Haggerty, J.A., Premoli Silva, I., Rack, F., and McNutt, M.K. (Eds.), 1995. Proc ODP, Sci. Results, 144: College Station, TX (Ocean Drilling Program).

214 Bessey Hall, Department of Geology, University of Nebraska-Lincoln, Lincoln. NE 68588-0340, U.S.A. sium, then silicon as weathering proceeds. In addition, a detailed comparison of these weathered horizons with modern counterparts can form an invaluable piece of the complete history of guyot formation. Combined with the fossil evidence, this study will provide an important tie point for the subsidence history of the different guyots by estimating duration of and an altitude range for soil formation based on depth of weathering and secondary mineral composition.

\section{Objectives}

Weathered mantles over guyot-constructing basalt were recovered at seven sites in the western Pacific, affording a unique opportunity to study paleosol development and preservation on subaerially erupted seamounts. The results of textural and mineralogic analyses of these weathered mantles can be compared to those from various parts of the Hawaiian Islands, which are subjected to a wide range of rainfall and length of exposure time to weathering in a subtropical setting. The objectives of this study are to (1) determine the types of alteration these basalts have experienced (hydrothermal, subaerial, phreatic), (2) determine the pedogenic processes responsible for some of the more striking features of the weathered mantles, and (3) bracket the climatic conditions responsible and the amount of time necessary for soil development on these seamounts.

\section{Previous Studies}

Recovery of possible paleosols from deep ocean drilling is rare. No clay deposits of the thickness recovered during Leg 144 (up to $28.6 \mathrm{~m}$ at Site 871 ) have been recovered from guyots to date. A $10-\mathrm{cm}$ 
interval thought to be a weathering surface was recovered from the Nintoku Seamount in the Emperor Chain during Deep Sea Drilling Project (DSDP) Leg 55 (Karpoff, 1980). This red claystone occurs between moderately altered alkalic basalt flows. Karpoff (1980) divided the interval into three parts: a yellowish red sandy claystone that gradually changes downward to a dark reddish brown claystone and then to a dark brown sandy claystone. Subhorizontal orientation of the alteration minerals was interpreted as relict of the lava flow. The clay mineral composition varies from kaolinite-rich with a trace of smectite at the top to abundant smectite with kaolinite at the base. The alteration mineral composition of the bulk sample varies from hematite and cryptocrystalline silica at the top to goethite and cryptocrystalline silica at the base. In transmission electron microscopy, tubular cylinders were observed, indicating the presence of halloysite. Titanomagnetite and rutile are unaltered throughout; olivine and plagioclase are preserved at the base. Karpoff argues that this clay mineral paragenesis is indicative of subaerial rather than submarine hydrothermal weathering, which would have generated smectite, chlorite, or zeolites, but not kaolinite. The hematite at the top of the weathering rind was induced by the thermal effect of the emplacement of the overlying lava flow (Karpoff, 1980).

A 30-m-thick, mid- to upper Eocene lateritic paleosol, correlative to laterites developed on basalt in northern Ireland, was recovered at DSDP Site 336 on the northeast flank of the Iceland-Faeroe Ridge, east of Iceland in the North Atlantic (Nilsen and Kerr, 1978). The lower part of this weathering horizon retains relict internal structures of the original lava flows and volcanic tuffs (Kahrin, 1976). The lower $8.5-\mathrm{m}$ overlying basalt comprises highly altered basaltic rubble dominated mineralogically by montmorillonite. Above this is a 1.5 -m-thick red clay with altered basalt clasts also dominated by montmorillonite but with increasing hematite, goethite, and anatase upward in the profile. Overlying this is $1.9 \mathrm{~m}$ of interlayered red and pale orange clay, which has the abrupt appearance of kaolinite at its base, and increasing kaolinite at the expense of montmorillonite upward. The top of the unit is $10.1 \mathrm{~m}$ of red clay dominated by kaolinite with hematite, goethite, and anatase. It contains no montmorillonite. Veinlet-like structures increase in density of occurrence upsection and are similar to features formed in modern Oxisols by the initial segregation of aluminum and iron (Nilsen and Kerr, 1978). There is an apparent upward enrichment in ferric iron, aluminum, and titanium and depletion of silicon, ferrous iron, and alkali and alkaline-earth metals. The vertical variations in chemical and mineral content of this unit are interpreted as products of subaerial weathering rather than hydrothermal alteration (Nilsen and Kerr, 1978). The multicolored layering is thought to result from repeated airfall/weathering events. The presence of kaolinite in the upper part of the profile confirmed earlier conclusions that the high northern latitudes had a warm, wet climate in the early Tertiary.

Soil development on the volcanogenic Kerguelen Plateau during the Early Cretaceous was inferred from the clasts of a soft-pebble conglomerate recovered at ODP Site 750 (Holmes, 1992). The internal structure of these pebbles was variable, as might be expected had they been derived by erosion of various horizons of soil developed over basalt. Some were massive clay, probably derived from the upper horizons of well-developed soils. Other clasts preserved the structure of the parent lava flow, including needle-like, plagioclase phenocrysts aligned as if by flow, but they were completely altered to clay. Such clasts are inferred to have been derived from the lowest horizons of soils, such as the $\mathrm{C}$ or $\mathrm{R}$ horizons. All clasts were soft at the time of deposition, as indicated by their flowage into one another. The clasts comprise kaolinite, gibbsite, smectite, and goethite.

Leg 143 sailed immediately before Leg 144 and recovered what may be lateritic paleosols at Site 866 on Resolution Guyot, although recovery was quite poor (Sager, Winterer, Firth, et al., 1993). The upper lava flows and breccias are highly altered to clay, and four clay units were recovered as clumps and pieces between flows of altered basalt. No horizons or other vertical gradations were reported. Some kaolinite is present, but where in the sequence is not clear (Sager,
Winterer, Firth, et al., 1993). More detailed work on this interval was not available at the time of this writing. The thin weathered horizon on Nintoku Seamount, a thick lateritic paleosol on the Thulean land bridge (now Iceland-Faeroe Ridge), and bits of paleosol hinting at intense weathering on the Kerguelen Archipelago did not prepare us for the recovery of thick weathering mantles over seamount basalt during Leg 144. Preservation and development of these mantles vary among the sites and form the foci of this study.

\section{MATERIALS AND METHODS}

\section{Texture and Mineral Composition}

Samples were taken of the weathered/altered zones of basalt from Sites 871 through 874 and 877 through 879 . Thin sections were made of 40 samples using vacuum impregnation with Spur resin. For the $\mathrm{X}$-ray diffraction (XRD) and textural analyses, a variety of techniques were used for sample preparation, depending upon the condition of the sample. Alteration minerals filling small vesicles, vugs, and thin veins were hand-scraped with stainless steel dental tools under a dissecting microscope onto a glass slide. The sample was dispersed using distilled water, smeared over the slide with a pick, and allowed to dry. If sufficient sample was available, it was put into a plastic sample carrier without wetting for a random mount. Larger samples were split for chemical and textural/XRD analysis. The textural/XRD split was split twice again to obtain a small sample for water content. Water content was determined by weighing the sample, oven-drying it at $105^{\circ} \mathrm{C}$ overnight, and weighing again. The larger split, generally about $5 \mathrm{~g}$, was wet-sieved through a $63-\mu \mathrm{m}$ sieve using distilled water. The sand fraction was dried and weighed for percent sand. The fines were shaken with distilled water, ultrasonified for $10 \mathrm{~min}$, and centrifuged at $2000 \mathrm{rpm}$ for up to $15 \mathrm{~min}$. This process was repeated up to six times. If centrifugation did not settle the sample, it was sent to the Sedigraph for textural analysis. Flocculated samples were treated with commercial Calgon (10-20 mL, $5 \%$ ). If they failed to deflocculate, they were tested for the presence of calcite using a drop of sample and $10 \% \mathrm{HCl}$. If calcite was present, the sample was treated with acetic acid buffered with sodium acetate to $\mathrm{pH} 5$ (Jackson, 1969) and washed with distilled water again. Nonrefractive organic matter was removed from a few black, organic-rich samples by heating with commercial bleach (sodium hypochlorite) for $15 \mathrm{~min}$ (Moore and Reynolds, 1989). If this failed to disperse the sample, or if calcite was not present, the sample was split again. One-half had iron oxides removed by the citratebicarbonate-dithionate (CBD) method of Jackson (1969), and the other half had kaolinite removed by treatment with $5 \mathrm{M} \mathrm{NaOH}$ (Singh and Gilkes, 1991). These samples were not analyzed for grain size.

The dispersed sample was loaded into a Sedigraph 5000ET, and the concentration was adjusted as needed by adding water or by allowing some water to evaporate at room temperature. The scans determined grain size from 63 to $0.25 \mu \mathrm{m}$. After Sedigraph analysis, various size fractions were removed using a pipette, following standard settling techniques using Stoke's law (e.g., Folk, 1980; Lewis, 1984). In general, the size fraction selected included both the silt $(63-2 \mu \mathrm{m})$ mode and clay $(<2 \mu \mathrm{m})$ mode. These samples were suctioned onto a cellulose nitrate filter membrane using a Milipore apparatus and the sample transferred to a glass slide for XRD analysis (Drever, 1973).

Mounted samples were scanned from $2^{\circ}$ to $45^{\circ} 2 \theta$ on a Scintag PAD V X-ray diffractometer using $\mathrm{CuK} \alpha$ radiation at $40 \mathrm{kV}$ and 35 $\mathrm{mA}$ with a graphite monochromator. Samples with peaks between 11 and $17 \AA$ were treated with ethylene glycol by placing them in a desiccator over ethylene glycol and heating in an oven at $65^{\circ} \mathrm{C}$ overnight. These samples were scanned again from $2^{\circ}$ to $30^{\circ} 2 \theta$.

\section{Chemical Analyses}

Thin sections were examined under a Jeol JSM 840A scanning electron microscope (SEM) equipped with a Kevex energy dispersive $\mathrm{X}$-ray analyzer (EDX). The SEM was operated at $10 \mathrm{kV}$. Uncoated 
thin sections were examined for element distribution. Only $\mathrm{Al}, \mathrm{Si}$, and Fe were detected during EDX analysis, and these corresponded to the same distribution of minerals as detected by XRD. Consequently, no results are illustrated here.

\section{RESULTS Hole 871C}

\section{Core Description}

The claystone deposits were separated from reef deposits on board Leg 144 as lithologic Unit III (Shipboard Scientific Party, 1993a). This lithologic unit was divided into three subunits on the basis of variations in texture, color, and content of lithoclasts. The upper subunit comprises $0.9 \mathrm{~m}$ of homogeneous gray clay with patches up to $1 \mathrm{~cm}$ thick of dark gray, fine-grained, sand-sized sediment (Fig. 1). This subunit is high in organic carbon (up to 13\%) and has variable amounts of carbonate, a reflection of bioturbation that concentrated aragonitic fossil material in burrows. The nannofossils give a late Paleocene age for this subunit (Shipboard Scientific Party, 1993a). The undated middle subunit (IIIB) is $12.1 \mathrm{~m}$ thick and comprises mottled, variegated clays. Munsell colors include dark red (10R 3/6), pale red (10R 6/3), olive brown (2.5YR 4/4), greenish gray (10G 7/2), and olive green. The matrix color is a light greenish gray (5BG 7/1). The lower subunit (IIIC) is $15.6 \mathrm{~m}$ thick and includes the upper part of the basalt pile, where volcaniclastic sandstone was recovered. It comprises clay, basalt "clasts," and sandy intervals. It is also undated.

The black, pyritic mud with calcareous fossils of upper Subunit IIIA is associated with the base of the platform's lagoonal deposit (Shipboard Scientific Party, 1993a). Benthic organisms living in the lagoon burrowed downward into the underlying, noncalcareous sediment and mixed lagoonal sediment, including mollusk fragments, nannofossils, and foraminifers, with the underlying clay. Shipboard chemical analyses of sediment in this interval reveal the gradational contact with irregular, downward declines in carbonate, inorganic carbon, total organic carbon, and sulfur contents (Shipboard Scientific Party, 1993a). The decline is irregular because some samples were taken from inside burrows (marine sediment) and others were taken from the nonfossiliferous matrix. The exact depth at which burrows disappear from the sediment is problematic, but their influence abruptly declines below a sharp color change from gray and black mottled to limonitic brown and tan mottled at 423.4 mbsf (Sample 144-871C-32R-1, $95 \mathrm{~cm}$ ).

Subunit IIIB contains no marine fossils, but has terrestrial organic debris (woody tissues and plant cuticle) in varying degrees of preservation and a low-diversity palynomorph assemblage, dominantly fungal but with some fern and six species of angiosperm pollen (Palmae?) extracted from Sample 144-871C-32R-1, 111-113 cm (Shipboard Scientific Party, 1993a). Preservation, diversity, and abundance of palynomorphs decreases downward over the four samples examined shipboard (423.6-434.9 mbsf). In the deepest sample examined, woody tissues are pyritized. The base of this unit is taken at the first appearance of basaltic rubble at 435.9 mbsf (Sample 144-871C-33R-3, $69 \mathrm{~cm}$ ). This gives a 12.5 -m-thick interval of mottled, nonfossiliferous clay.

The most striking feature of the clay of Subunit IIIB is the mottling (PI. 1, Fig. 1). The mottles are 1 to $4 \mathrm{~cm}$ across and principally yellowish brown (10YR 5/8), light greenish gray (5BG 7/1), a pale red ( $5 R 5 / 6$ to $4 / 6$ red) that intensifies to dark red ( $5 R 3 / 8$ ), and a magenta that defies comparison to a Munsell color but comes closest to dark red ( $5 \mathrm{R} 2.5 / 6)$. The matrix color varies from light greenish gray to yellowish brown, and the red mottles appear, become dominant, and disappear locally again downhole. These variations in matrix color and dominance of mottle color occur over intervals of 10 to $50 \mathrm{~cm}$ but are not repeatable sequences. That is, each successive interval may have any combination of mottle colors or background. The brown mottles may be partly surrounded by or have no relationship to the red mottles. After samples are allowed to dry, they become very hard and could only be crumbled with difficulty; however, after they were remoistened by being placed in a sealed sample bag with a moist sponge, they become soft again. Beginning at $433.3 \mathrm{mbsf}$ (Sample 144-871C-33R-1, $100 \mathrm{~cm}$ ), the red mottles fade and disappear. The brown mottles take on a "fluffy" aspect, making it difficult to obtain a smooth surface for photography. The light gray color forms the matrix of this deeper interval. This pattern persists downhole until the first in-situ basalt cobble, encased in yellowish brown clay, is found at 435.9 mbsf (Section 144-871C-33R-3, $69 \mathrm{~cm}$ ). Farther downhole, the brown mottles increase in abundance, as do the basalt cobbles. The basalt cobbles are completely altered to clay; although they may superficially look like basalt, they are easily peeled, scratched, or crumbled with a fingernail. These pieces begin to retain vesicles filled with white, secondary minerals at $442.2 \mathrm{mbsf}$ (Sample 144-871C-34R-1, $50 \mathrm{~cm}$ ).

Epiclastic volcanic deposits composed of altered basalt pebbles and heavily cemented by iron oxides occur over intervals 144-871C$35 \mathrm{R}-1,82-131 \mathrm{~cm}$, and $-36 \mathrm{R}-2,70-80 \mathrm{~cm}$. The lower deposit is highly drilling disturbed. The upper is poorly sorted and crudely laminated, with an upward fining of clast size over interval 144$871 \mathrm{C}-35 \mathrm{R}-1,95-104 \mathrm{~cm}$. These deposits are interbedded with highly altered lava flows and breccias. The margins of the lava flows were not preserved, and whether they were erupted subaerially or otherwise would require the most tentative interpretation (Shipboard Scientific Party, 1993a). The interbedded sediment is also highly altered, but as the clasts are not highly vesicular, they are interpreted as not being the products of explosive eruptions but perhaps talus or other erosional debris (Shipboard Scientific Party, 1993a).

\section{Petrography}

In thin section, black, opaque, sand-sized specks appear throughout the mottled clay (PI. 2, Fig. 2). Examination under SEM with EDX indicates that these specks are composed of iron; thus, they are interpreted as hematite. They may occur within mottles of any color or in the background matrix. The mottles appear in thin section as they appear with the hand lens: the boundaries are diffuse and the colors permeate into one another (Pl. 2, Fig. 2). The brown mottles commonly have lithified "clasts" at their centers, which are irregular in outline and less than $1 \mathrm{~cm}$ in diameter. The red and gray mottles have no such locus. Only the lithified brown "clasts" have sharp contacts. In thin section, these features may have concentric internal structure (concretions; see Pl. 2, Fig. 1) or not (glaebules; see Pl. 2, Fig. 3). The epiclastic volcanic deposit is composed of white clasts with internal, concentric features (PI. 2, Fig. 4). The clasts were soft at the time of deposition, as indicated by their flowing into one another in response to compaction after deposition of overlying material (PI. 2, Fig. 5). Some of the clasts are penetrated, some are surrounded by iron oxide or oxyhydroxide cement.

\section{Mineral Composition, Texture, and Chemical Composition}

The mineral suite of the clay intermixed with lagoonal carbonate sediment (Subunit IIIA) is dominated by kaolinite with a faint trace of smectite (Figs. 1,2A). There is no variation in mineral composition with grain size from the silt mode $(4 \mu \mathrm{m})$ to the clay mode $(1 \mu \mathrm{m})$. The mottled clay (Subunit IIIB) is dominated by kaolinite, with anatase $\left(\mathrm{TiO}_{2}\right)$, goethite $(\mathrm{FeOOH})$, and hematite $\left(\mathrm{Fe}_{2} \mathrm{O}_{3}\right)$ also present in most samples (Figs. 1-3). A small amount of gibbsite is present in a red mottle from Sample 144-871C-32R-2, 105-107 cm. Bright red, light (white to steel blue), and limonitic brown mottles were separated for X-ray analysis. As might be expected, the red and brown mottles show concentration of Fe-bearing minerals. The red mottles are dominated by goethite and hematite (Fig. 4A), the brown mottles by goethite (Fig. 4B), and the light mottles by kaolinite (Fig. 4C). In addition, brown mottles contain a trace of smectite. When iron oxides were removed by the CBD method, kaolinite and smectite traces become more clear (Fig. 2B-D). When clays were removed by the 


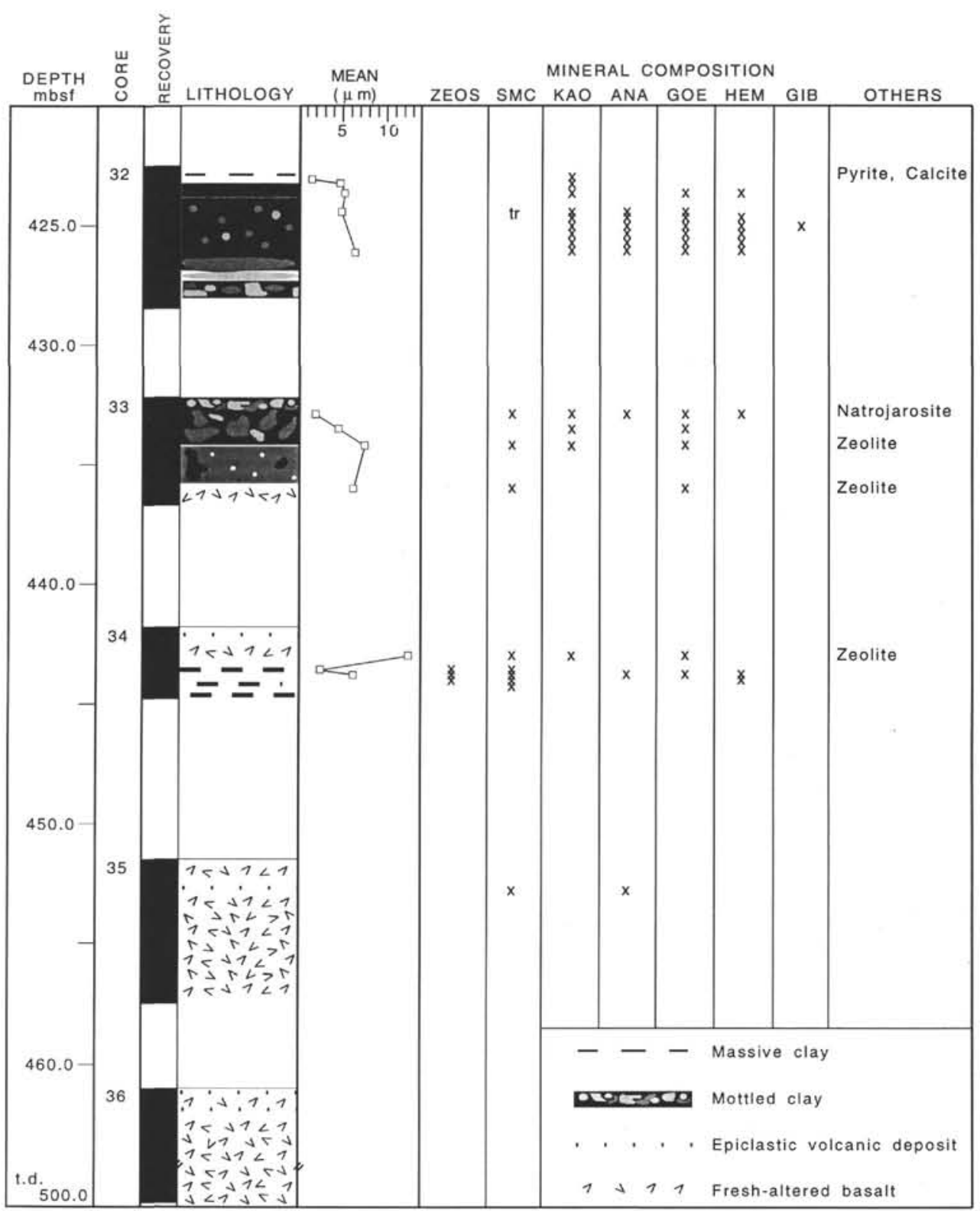

Figure 1. Stratigraphy, texture, and mineral composition of clay units in Hole 871C, Limalok Guyot. ZEOS $=$ zeolites, $\mathrm{SMC}=\mathrm{smectite,} \mathrm{KAO}=\mathrm{kaolinite}, \mathrm{ANA}$ $=$ anatase, $\mathrm{GOE}=$ goethite, $\mathrm{HEM}=$ hematite, $\mathrm{GIB}=$ gibbsite, $\mathrm{x}=$ present, and $\mathrm{tr}=$ trace. $\mathrm{t} \cdot \mathrm{d} .=$ total depth.

$\mathrm{NaOH}$ method, anatase, goethite, and hematite peaks emerged (Fig. 3). Smectite peaks become larger and sharper downcore whereas kaolinite peaks diminish, indicating an increase in smectite content as kaolinite decreases (Fig. 2). Kaolinite disappears below Sample 144$871 \mathrm{C}-34 \mathrm{R}-1,120 \mathrm{~cm}$, and zeolites (including analcime) appear below this interval (Figs. 1, 3C, D). In smear slides one of the zeolites appears fibrous. Goethite persists but hematite becomes more abundant downhole (Fig. 3). Natrojarosite $\left[\mathrm{NaFe}_{3}\left(\mathrm{SO}_{4}\right)_{2}(\mathrm{OH})_{6}\right]$ occurs in trace amounts in Sample 144-871C-33R-1, 68-70 cm. The white clay infilling paleovugs of the basalt is a smectite (Fig. 5A).

Mean grain size varies nonsystematically with depth (Fig. 1) and ranges from $1.54 \mu \mathrm{m}$ in the decalcified marine clay to $12.5 \mu \mathrm{m}$ in Sample $144-871 \mathrm{C}-34 \mathrm{R}-1,120-122 \mathrm{~cm}$. This variation is caused by the variable presence of goethitic concretions.

\section{Hole 872C}

Ten centimeters of dark gray clay, dated as late Oligocene by planktonic foraminifers (Shipboard Scientific Party, 1993b) overlies altered, vesicular basalt in Hole $872 \mathrm{C}$ (Fig. 6). This material has a mean grain size of $1.70 \mu \mathrm{m}$ and is composed of smectite, kaolinite, and plagioclase.

\section{Hole 873A}

\section{Core Description}

Beneath Campanian foraminifer limestone, noncalcareous, red clay was recovered in Cores 144-873A-12R and -13R, 155.6-175.1 mbsf (Fig. 7). Downhole logging indicates that the upper $4.1 \mathrm{~m}$ of the section was not recovered: a sudden increase in thorium and aluminum but not uranium, a decrease in resistivity, and an increase in borehole diameter occurs at 151.5 mbsf (Shipboard Scientific Party, 1993c). The recovered clay is massive, dark red (10R 3/6), and largely uniform in the upper $1.7 \mathrm{~m}$ with some streaks and blebs of white material. No soil structure as peds was observed. Beneath the massive interval is a drab, 65-cm-thick, mottled interval (144-873A-12R-2, $23-88 \mathrm{~cm})$ with dark red (10R 3/4), pale red (10R 6/4), and pinkish 


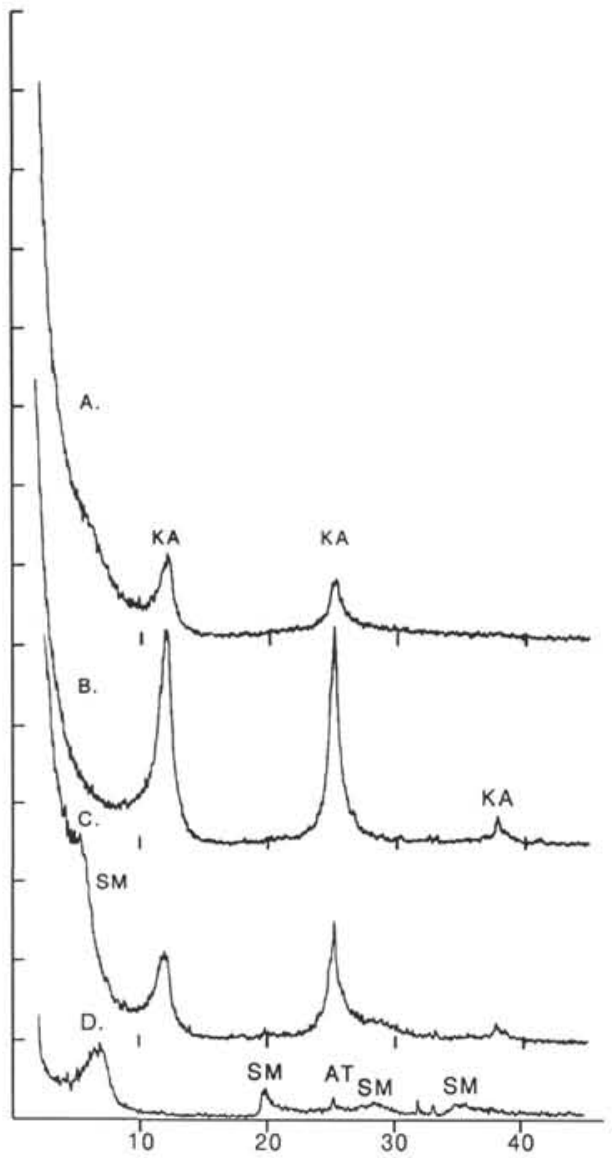

Figure 2. X-ray diffraction results showing downhole variation in mineral composition, Hole $871 \mathrm{C}$, from dominance by kaolinite at the top to dominance by smectite at the base. Iron oxides/hydroxides have been removed from these samples by the CBD method. $Y$-axis is intensity in counts per second (thousands), and $X$-axis is ${ }^{\circ} 2 \theta$, CuK $\alpha$ radiation. A. Sample 144-871C-32R-1, 50-52 $\mathrm{cm},<1 \mu \mathrm{m}$ fraction, marine sediment overlying terrestrial unit; calcite removed by $\mathrm{Na}$ acetate, nonrefractory organic matter removed by bleach. B. Sample 144-871C-32R-2, 36-38 cm, bulk sample. C. Sample 144-871C-33R-1, 68-70 $\mathrm{cm}$, bulk sample. D. Sample 144-871C-34R-2, $45-47 \mathrm{~cm}$, bulk sample. $\mathrm{KA}=$ kaolinite, $\mathrm{SM}=$ smectite, and $\mathrm{AT}=$ anatase.

gray $(5 \mathrm{YR} 7 / 2)$ mottles that are $1-4 \mathrm{~cm}$ across. The matrix is olive ( $5 \mathrm{Y}$ $5 / 4)$. This interval changes gradually downhole by the appearance of and increasing concentration of thick brown and thin pink veins, which form a reticulated pattern (PI. 1, Fig. 2). The veins are zoned, with dark reddish brown (2.5YR 3/4) edges and thin pink (7.5YR 8/3) centers. The veins cut vertically and horizontally across a bluish purple clay matrix that most closely resembles Munsell color 5B 5/1 (bluish gray). In some places, the larger "veins" taper and bifurcate downward, but most of them cut around the matrix, forming bluish gray polygons between them, some in almost liesegang-type bands. Thin, red (7.5R 4/8), iron oxide-rich veins cut across both matrix and larger veins. Pieces of basalt with calcite-filled veins appear abruptly in Core 144-873A-14R.

\section{Petrography}

In thin section, the massive clay unit comprises red clay with inclusions of black crystals that appear to be ferruginized woody material (Pl. 2, Fig. 6). These and concentrations of iron float in the clay/Fe oxide matrix. The veined interval comprises massive clay in the bluish gray polygons, surrounded by brown veins with relict parent basalt structure in the form of plagioclase phenocrysts pseudomorphed by clay and iron oxides (Pl. 3, Figs. 1-4). The downhole,

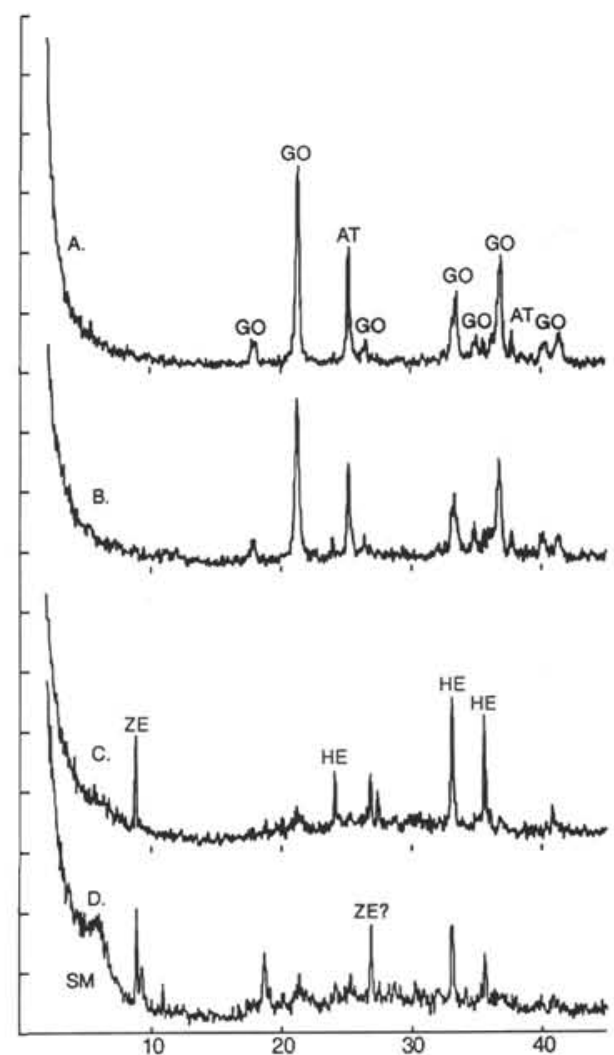

Figure 3. X-ray diffraction results showing downhole variation in mineral composition, Hole $871 \mathrm{C}$. Goethite and anatase diminish downhole while hematite and a zeolite increase. Kaolinite has been removed from these bulk samples by the $\mathrm{NaOH}$ method. $Y$-axis is intensity in counts per second (thousands), and $X$-axis is ${ }^{\circ} 2 \theta$, CuK $\alpha$ radiation. A. Sample $144-871 \mathrm{C}-32 \mathrm{R}-3,36-38 \mathrm{~cm}$. B. Sample 144-871C-33R-1, 68-70 cm. C. Sample 144-871C-34R-2, 45-47 cm. D. Sample $144-871 \mathrm{C}-34 \mathrm{R}-2,78-80 \mathrm{~cm}$. GO = goethite, $\mathrm{AT}=$ anatase, $\mathrm{HE}=$ hematite, $\mathrm{SM}=$ smectite, and $\mathrm{ZE}=$ zeolite.

relict basalt structure becomes evident in the bluish gray polygons as well, but only immediately adjacent to the brown veins (Pl. 3, Fig. 4). The pink veins appear full of authigenic clay (Pl. 3, Figs. 2, 3).

\section{Mineral Composition, Texture, and Chemical Composition}

The clay unit of Hole $873 \mathrm{~A}$ is rather simple mineralogically, comprising kaolinite, goethite, and hematite (Fig. 7). The white material in the thin veins and blebs of the upper, massive red clay is identified as natroalunite (Fig. $8 \mathrm{~A} ; \mathrm{NaAl}_{3}\left[\mathrm{SO}_{4}\right][\mathrm{OH}]_{6}$ ). This mineral has been reported from a lateritic soil profile (in the surface horizon and in the saprolite) developed over the Deccan Traps in the Kutch region of India (Chitale and Güven, 1987). The lateritic weathering there took place in the Paleocene; later, during the middle Eocene, the area was submerged and lignites and pyritic black shales were deposited atop the laterite.

The bluish gray polygons were separated from the thick brown veins and thin pink veins using Sample 144-873A-12R-3, 114-118 $\mathrm{cm}$. Each separate is composed of kaolinite and goethite (Fig. 8B-D). The polygon centers comprise kaolinite, goethite, and anatase. The brown veins exhibit sharp hematite peaks, which the other separates do not, and the kaolinite peaks are reduced relative to the other separates. A suggestion of smectite is present in the brown veins. The thin pink veins comprise kaolinite and goethite. Smectite appears in abundance only in the very fine $(<0.25 \mu \mathrm{m})$ fraction of the deepest sample (Sample 144-873A-13R-CC; Fig. 8E). 


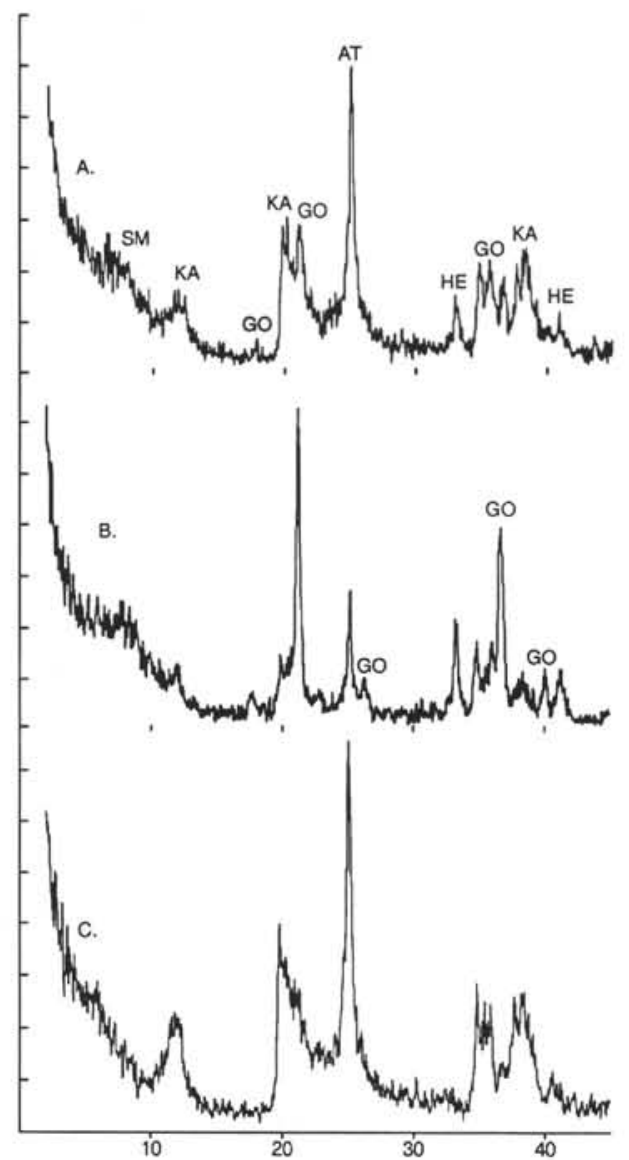

Figure 4. X-ray diffraction results of Sample 144-871C-32R-1, 113-115 cm, separated into various color mottles. The colors of the mottles show no systematic variation with depth, but red mottles are much less common below $432.5 \mathrm{mbsf} . Y$-axis is intensity in counts per second (thousands), and $X$-axis is ${ }^{\circ} 2 \theta$, CuK $\alpha$ radiation. A. Bright red mottle. B. Brown concretion. C. Gray mottle. $\mathrm{SM}=$ smectite, $\mathrm{KA}=$ kaolinite, $\mathrm{GO}=$ goethite, $\mathrm{AT}=$ anatase, and $\mathrm{HE}$ $=$ hematite.

\section{Hole 874B}

\section{Core Description and Petrography}

The clay unit recovered from Hole $874 \mathrm{~B}$ is approximately $14.9 \mathrm{~m}$ thick (Fig. 9). At its base, it merges into highly altered basalt. Black, massive, pyritic clay gradually changes to mottled gray clay downhole, and then to gray clay with white, mineral-filled spots, which evidently are relict basalt vesicles (Pl. 1, Fig. 3). Abruptly at Sample 144-874B$21 \mathrm{R}-1,125 \mathrm{~cm}$, the color changes from gray to bright red (Pl. 1, Fig. $3)$. The unit then gradually changes downward from red clay $(7.5 R 5 / 4)$ through dark red clay (7.5R $3 / 8)$ to black basalt altered to clay. The lower contact occurs at the base of Section 144-874B-22R-3. The upper, gray clay contains woody and cuticular fragments, fern spores (Leiotriletes), fungal spores, a monolete fern spore, and some foraminiferal linings (Shipboard Scientific Party, 1993d). In addition, there are large benthonic foraminifers and calcareous nannofossils that indicate a Campanian age (Shipboard Scientific Party, 1993d).

\section{Mineral Composition, Texture, and Chemical Composition}

The mineral composition varies very little throughout this unit. In the upper, gray zone, the only clay mineral present is kaolinite (Fig. 9). Pyrite is also present. Vestiges of goethite were detected in the silt-sized fraction but not in the clay-sized one. At the color contact (Sample 144-874B-21R-1, 126-128 cm), kaolinite and goethite are

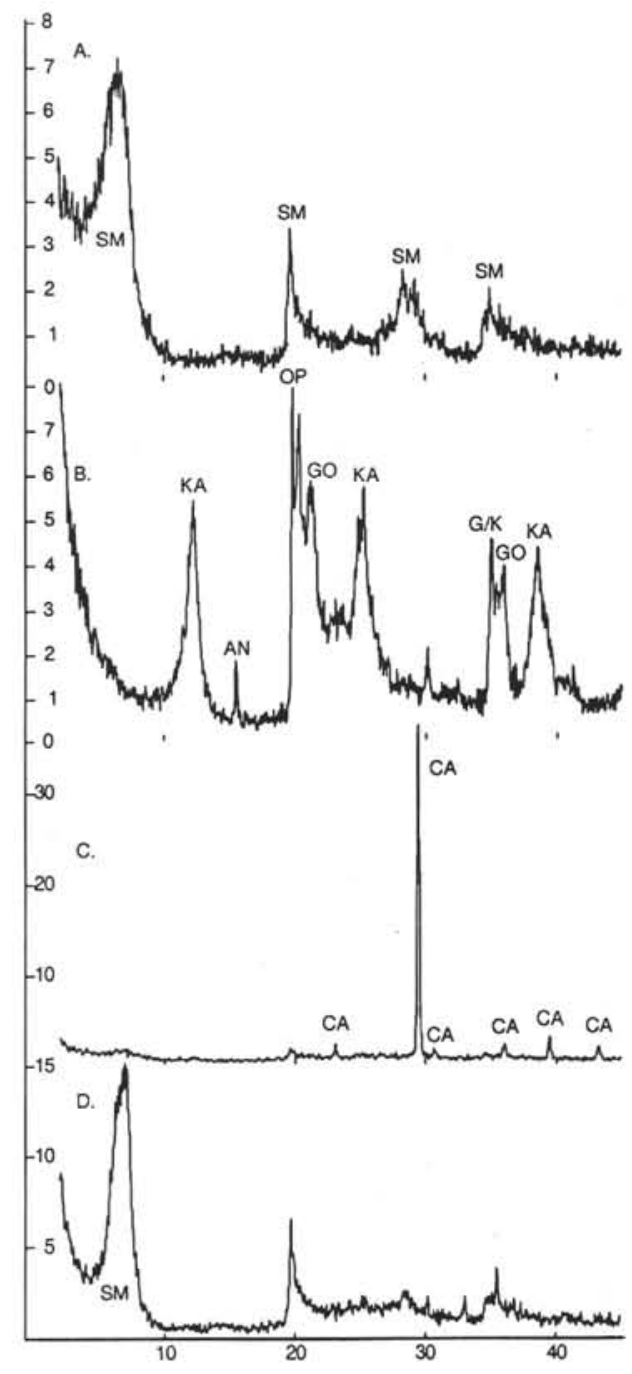

Figure 5. X-ray diffraction results of separated vesicle fills showing variation of composition of alteration minerals. $Y$-axis is intensity in counts per second (thousands), and $X$-axis is ${ }^{\circ} 2 \theta, \mathrm{CuK} \alpha$ radiation. A. Sample $144-871 \mathrm{C}-34 \mathrm{R}-2$, $129-131 \mathrm{~cm}$. B. Sample 144-874B-22R-2, 113-114 cm. C. Sample 144-877A20R-4, 98-100 cm. D. Sample 144-19R-1, 120-124 cm. SM = smectite, KA $=$ kaolinite, $\mathrm{GO}=$ goethite, $\mathrm{OP}=$ opal $-\mathrm{CT}, \mathrm{AN}=$ analcime, $\mathrm{CA}=$ calcite, and $\mathrm{G} / \mathrm{K}=$ overlapping peaks of goethite and kaolinite.

present with hematite. These form the matrix throughout this unit and kaolinite, analcime, and opal-CT fill the vesicles (Fig. 5B). Although an anomalous, low-iron layer was detected by the gamma spectrometer between 165 and 166.5 mbsf (Section 144-874B-21R-2, $70 \mathrm{~cm}$, to base of 144-874B-21R; Shipboard Scientific Party, 1993d), there was no decrease in intensity of goethite or hematite peaks in this interval. Only one grain-size analysis was made of this unit, as the relict basalt structure indicates this unit is not disrupted by pedogenesis and hence cannot have translocation of clays. Mean grain size is $6 \mu \mathrm{m}$.

\section{Hole 877A}

\section{Core Description}

In Core 144-877A-20R, calcareous grainstone grades downward into a 1-m-thick unit comprising interbeds of argillaceous limestone and organic-rich clay (Fig. 10). This overlies a 20-cm-thick black pyritic peat, which in turn overlies gray mottled clay. The color changes abruptly at a wavy boundary to bright red in Sample 144877 A-20R-3, 90-92 cm. This material turns tan and then black as it 


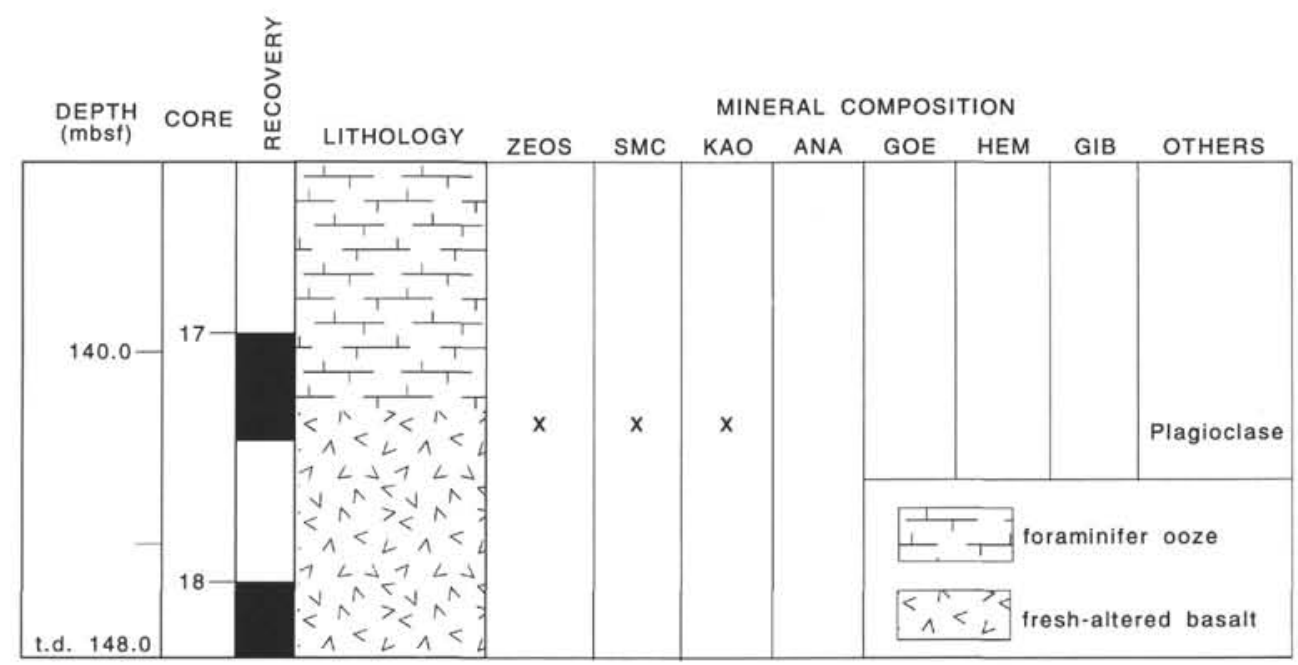

Figure 6. Stratigraphy, texture, and mineral composition of sediment/basalt contact at Hole 872C, Lo-En Guyot. For explanation of symbols and abbreviations, see Figure 1.

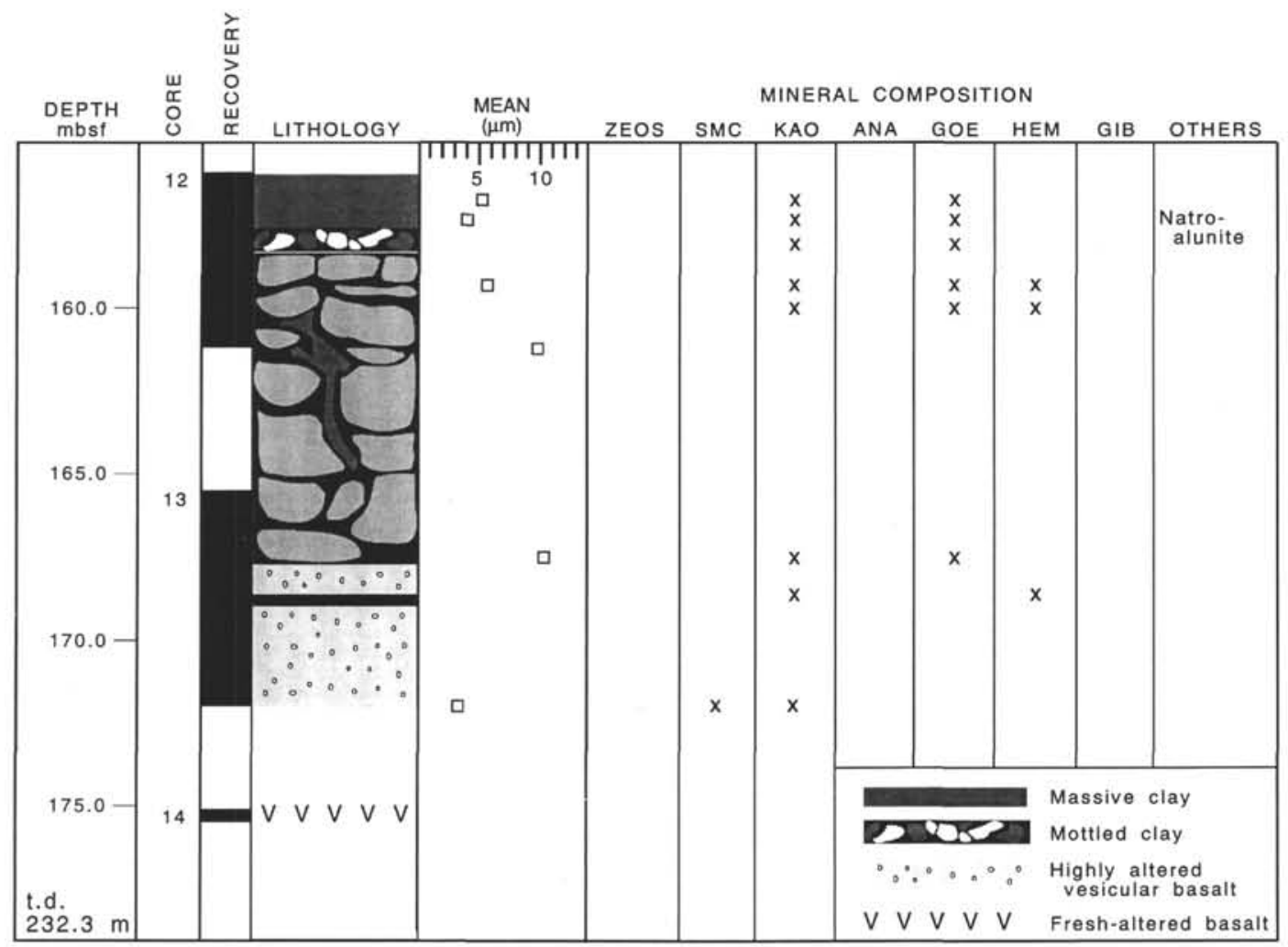

Figure 7. Stratigraphy, texture, and mineral composition of clay in Hole 873A, Wodejebato Guyot. For explanation of symbols and abbreviations, see Figure 1.

gradually merges downhole into basalt. The base of the clay unit is at Sample 144-877A-20R-4, $100 \mathrm{~cm}$, where fresher basalt is first recovered. The probable nonmarine unit, from the top of the peat to the top of the basalt, is $5.0 \mathrm{~m}$ thick.

A late Campanian, calcareous nannofossil assemblage with reworked Cenomanian taxa was recovered in the argillaceous limestone above the clay in Sample 144-877A-20R-1, 42-45 cm (Shipboard Scientific Party, 1993e). Marine mollusk fragments are recovered down to Sample 144-877A-20R-1, $77 \mathrm{~cm}$. Thus the upper meter of the clay unit is marine. Beneath this bed lies peat with plant debris concentrated along bedding planes. Beneath the peat, the mottled clay interval is reported in shipboard descriptions to contain "roots" but these were not documented by photographs. The mottles in this interval are largely horizontal although some are vertical. A few bifurcate, but the bifurcations are upward (Pl. 1, Fig. 4). None of the mottles tapers downward. A palynology sample taken at 144-877A-20R-2, $96-98 \mathrm{~cm}$, contained moderately preserved woody tissues and cuticle; no root material was reported (Shipboard Scientific Party, 1993e). I was not able to find any roots, root casts, or root haloes in this interval. No marine fossils were reported, and shipboard organic carbon analysis indicates the presence of terrestrial (type III and IV) organic debris (Shipboard Scientific Party, 1993e). The interval is probably 


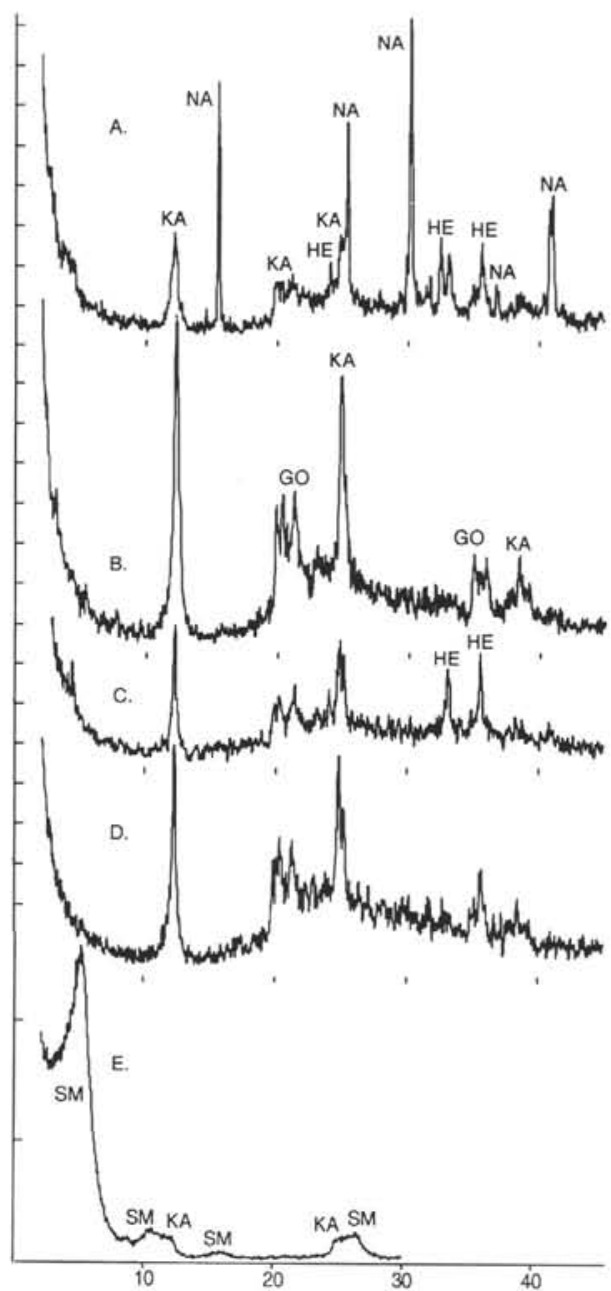

Figure 8. X-ray diffraction results from the clay unit at Site $873 . Y$-axis is intensity in counts per second (thousands), and $X$-axis is ${ }^{\circ} 2 \theta$, CuK $\alpha$ radiation. A. Sample $144-873$ A-12R-1, 135-137 cm. Separated white material filling veins in upper, massive red clay is natroalunite. B. Sample 144-873A-12R-3, 114-118 $\mathrm{cm}$. Separated thin, pink veins. C. Sample 144-873A-12R-3, 114-118 cm. Separated brown "veins." D. Sample 144-873A-12R-3, 114-118 cm. Separated centers of polygons between brown and pink veins. E. Sample 144-873A-13R$\mathrm{CC},<0.2 \mu \mathrm{m}$. Smectite occurs only at the base of this unit. $\mathrm{SM}=$ smectite, $\mathrm{KA}$ $=$ kaolinite, $\mathrm{NA}=$ natroalunite, $\mathrm{HE}=$ hematite, and $\mathrm{GO}=$ goethite .

terrestrial, but the mottles are mottles; they are not root remains or root-influenced. Mottling can be caused by invertebrate bioturbation in marginal marine sediment. When the chroma is 2 or less, it may have been generated by inhomogeneous microbial activity in poorly drained, water-saturated soils (e.g., Soil Survey Staff, 1975). The color given for this interval shipboard is 10YR 6/1 (chroma =1). The mottled interval appears to have a relict structure of some type of epiclastic volcanic deposit, with different paleoclasts altered to slightly different shades of gray and pink (PI. 1, Fig. 5). We could not make any satisfactory thin sections from this material.

\section{Mineral Composition, Texture, and Chemical Composition}

The clay mineral composition varies downhole from kaolinite, to a mixture of kaolinite and smectite, to smectite (Figs. 10,11). In the upper, gray zone, natrojarosite appears, as it did in the clay at Site 871 (Fig. 11A). Deeper in the reduced profile, traces of goethite and hematite persist (Fig. 11B). Smectite first appears in Sample 144877A-20R-3, 52-54 cm (Fig. 11C), but then disappears in Sample
144-877-20R-3, 129-131 cm (Fig. 11C). The green and white minerals filling the vesicles of Sample 144-877A-20R-4, 98-100 cm, are calcite and smectite (Fig. 5C). Overall, grain size is finer in the deeper, oxidized part of the unit (Fig. 10).

\section{Hole 878A}

\section{Core Description and Petrography}

Two sedimentary units occur intercalated with fresher basalt in Hole 878A (Shipboard Scientific Party, 1993f). The upper unit (in interval 144-878A-80R-1, 87-145 cm) is an altered epiclastic volcanic deposit. It is crudely laminated and poorly sorted, with three 2-cmthick, upward-fining intervals in interval 144-878A-80R-1, 118-139 $\mathrm{cm}$. It contains pebbles that range up to $7 \mathrm{~mm}$ across and are embedded in a clay matrix. They are composed of altered basalt. In thin section, some pebbles have relict basalt structure, some are composed of a white clay, and the remainder are composed of iron oxides. They are deformed by postdepositional compaction.

The lower unit occurs in the interval from 144-878A-85R-2, 135 $\mathrm{cm}$, to $-86 \mathrm{R}-2,18 \mathrm{~cm}$, and comprises red clay (Fig. 12). The relict structure of the parent massive lava flows and basaltic breccia is clearly visible over most of this interval. It looks, in fact, just like basalt, except that, in the upper part, it is bright red, and throughout it is composed entirely of clay. Paleovesicles are filled with brown to yellow iron oxide/oxyhydroxide alteration minerals. The color varies downward from various shades of red (e.g., 10R 4/1, dark reddish gray; $5 \mathrm{R} 2 / 2$, blackish red; $10 \mathrm{R} 4 / 6$, moderate reddish brown) through dusky yellow brown (10YR $2 / 2)$ to black.

\section{Mineral Composition and Texture}

Smectite and hematite comprise the mineral suite. Kaolinite, goethite, and hematite occur in the weathered basalt (Fig. 12). Grain size was not determined for any of these samples.

\section{Hole 879A}

\section{Core Description}

Upper Aptian marine sediment, comprising alternations of argillaceous limestone, bioclastic sandstone, volcaniclastic sandstone and conglomerate with bivalves, overlies $28.4 \mathrm{~m}$ (Sections 144-879A19R-1 to -21R-2) of claystone with relict structure of an epiclastic volcanic deposit (Fig. 13; interval 144-879A-21R-1, 0-66 cm; Shipboard Scientific Party, 1993g). There are intervals within this unit of highly lithified clay that look like basalt but can be scored with a fingernail. Clasts contain vesicles filled with alteration minerals (PI. 1, Fig. 6). The alteration minerals are in turn altered by a red stain. The clay matrix of the altered breccia is weak red (10R 4/4), darkening downward to dark red (10R 3/6) and dusky red (10R 3/3).

\section{Petrography}

Sample 144-879A-21R-1, 67-70 cm, reveals the source of the concentric features in some of the clasts of the soft pebble conglomerates. The relict structure of the basalt is clearly visible in thin section, including the presence of plagioclase phenocrysts now altered to clay. The concentric nature of the replacement clay is visible, along with remnants of cleavage planes (Pl. 3, Figs. 5, 6).

\section{Mineral Composition, Texture, and Chemical Composition}

The mineral composition of this unit is highly variable downhole, depending upon the degree of alteration of the clasts in the conglomerate and breccia. The vesicles of clasts in the breccia of Sample 144-879A-19R-1, 120-124 cm, are filled with smectite and opal-CT (Fig. 5D). The matrix comprises smectite, kaolinite, and goethite. 


\section{DISCUSSION}

\section{Are the Clay Units Soils or the Products of Hydrothermal Alteration?}

Retallack (1988) lists three main features of sediment for its identification as a paleosol:

1. The presence of root traces (in post-Silurian deposits).

2. The presence of soil horizons, produced by self-forming processes (Soil Survey Staff, 1975), which may have sharp to diffuse vertical boundaries. They are differentiated on the basis of changes in organic matter content, texture, color, structure, nodules or concretions, clay skins, etc.

3. Soil structure in the form of peds (stable aggregates of soil material). Wright (1992) pointed out that peds are readily destroyed by burial compaction, but where preserved, tend to increase in size downward.

In addition to these three main features, Retallack (1988) uses another criterion: the stratigraphic position of the soil, particularly its association with unconformities.

Wright (1992) pointed out that, although many workers feel that pedogenesis begins with biological activity in a weathering zone, the fossilization potential of organic structures, such as roots, is so low that this is not the best criterion for recognizing paleosols. He offered the following criteria in addition to those of Retallack.

1. Color, which includes (a) reddening or rubefaction, also caused by early diagenesis but generally increasing upward in a soil and with diffuse boundaries (although reddening may increase downward in temperate soils); and (b) mottling, usually associated with high water tables and/or poor drainage. Mottling also occurs in fine-grained marine sediment, usually as a result of bioturbation (e.g., Potter et al., 1980) and in intensely weathered (lateritic) soils (e.g., Carroll, 1970; Mohr et al., 1972; McFarlane, 1976).

2. Destratification, which is usually effected by bioturbation. Rates of destratification are lacking; Wright (1992) cites Harden (1982) as estimating $10,000 \mathrm{yr}$ for this process in alluvial terrace soils of California.

3. Mineralogy and geochemistry, that is, downward variations generally reflect more intensive leaching of mobile elements $(\mathrm{Ca}, \mathrm{Na}$, $\mathrm{K}, \mathrm{Mg}, \mathrm{Si}$ ) from the upper horizons. clay).

4. Micromorphology, including sepic structure (usually aligned

These criteria will be addressed in turn below.

\section{Root Traces and Other Fossil Evidence}

No unequivocal root traces were observed in the Leg 144 terrestrial deposits. The mottles in the clay at Site 871 (PI. 1, Fig. 1) might be interpreted as root haloes, but root haloes in red paleosols are usually drab colored (bluish or greenish gray; Retallack, 1988). A drab color (light greenish gray) forms the matrix in some parts of the clay in Hole $871 \mathrm{C}$ and the mottles in other parts. The color variations of the mottles are nonsystematic: any color may form a mottle center, and any other color may partly surround it. The mottles show no textural variation among them or between mottles and the enclosing matrix, indicating that they were not formed by infilling of cavities left by roots with material from above (krotovinas). This suggests that bacterial reduction around roots is not the cause of the mottling. The mottling is probably related to horizon development, as discussed below.

Bifurcating features lined with iron oxides in Cores 144-873A$12 \mathrm{R}$ and $-13 \mathrm{R}$ possess the superficial appearance of root traces (PI. 1, Fig. 2), but relict basalt structure is visible in thin sections cutting across these features (Pl. 3, Figs. 1-4). The relict parent structure could not have been preserved if roots had pushed their way through softened basalt. In addition, the absence of root traces in the massive clay above these features further suggests that they are not root traces. Although roots were reported from the clay of Site 877, the absence of downward tapering and downward bifurcation indicates the features possibly described as roots are actually mottles or possibly burrows (Pl. 1, Figs. 4, 5).

Although root traces are absent, terrestrial organic matter occurs as woody tissue, plant cuticle, and fern and angiosperm pollen in the clay units of Sites 871,874 , and 877 . The only marine fossils or organic matter reported occur as burrow infill from overlying lagoonal sediment at Sites 871 and 874 (Premoli Silva, Haggerty, Rack, et al., 1993).

\section{Soil Horizons}

\section{Site 871}

Mottles of gray and black mud in the upper meter of the clay unit at Site 871 were no doubt generated by the burrowing of lagoonal infauna after the weathered horizon subsided below sea level. The presence of aragonitic and calcitic fossil shelly material in some of the burrows is the strongest evidence for this. The marine-influenced clay may have been deposited after subsidence, or it may be a reworked surface (A) horizon. In support of the latter hypothesis, a considerable amount of terrestrial organic matter is present as pollen and woody tissue in this interval (Shipboard Scientific Party, 1993a), and the clay mineral composition is identical to the material below it (Fig. 2A-C). How much reworking an A horizon can stand before it is, in fact, a sedimentary deposit is another question that will not be addressed here. If not a reworked $\mathrm{A}$ horizon, this deposit is certainly derived from material very like the clay immediately beneath it (Fig. 2A-C).

Brilliant red, magenta, yellowish brown, and drab gray mottles persist over a 10 -m-thick interval in Hole $871 \mathrm{C}$ beneath the marineinfluenced sediment (Pl. 1, Fig. 1) and overlie a 2.5-m-thick interval of drab gray clay with yellowish brown mottles. These features are similar to plinthite in modern soils of tropical to subtropical regions. Plinthite is a mixture of clay with some diluents such as quartz and is iron-rich and humus-poor; the iron is segregated from the background clay, forming a reticulate, platy, or polygonal pattern (Soil Survey Staff, 1975). Upon exposure to air, plinthite hardens irreversibly to ironstone, although this hardening may require repeated wetting and drying cycles. The mottles of Hole $871 \mathrm{C}$ were formed by the segregation of iron, as indicated by the variation in mineral composition (Fig. 4). The drab gray mottles are dominantly kaolinitic; the red and brown mottles have concentrations of hematite and goethite, respectively. The segregation of iron and subsequent mottling of soils is thought to take place under saturated conditions, that is, in soils of low-lying areas or where drainage is restricted (Soil Survey Staff, 1975). A high water table allows reducing conditions and mobilization of iron to develop when soil bacteria consume the available oxygen (e.g., Bohn et al., 1985, p. 325). But the soil must dry out again for the iron to precipitate in the oxidized state, requiring that the water table fluctuate over the thickness of the mottled zone, which is $12.5 \mathrm{~m}$ at Site 871. A thick mottled zone is a common feature of laterite formed at higher elevations, up to $1555 \mathrm{~m}$ in Uganda, where drainage is not restricted (Johnson and Williams, 1961, in McFarlane, 1976). McFarlane (1976) has proposed that the mottled zone of these laterites develops near the top of a water table that need not fluctuate over a dozen meters, but declines steadily over time as the landscape deflates. Mohr et al. (1972, p. 218) also proposed a gradually lowering water table to account for thick mottled zones in Oxisols. The 2.5 -m-thick gray zone beneath the mottled one is similar to a leached "pallid zone" underlying some mottled zones of many lateritic soils (McFarlane, 1976). A pallid zone is a pale-colored zone underlying laterite and/or a mottled zone; it is pale because iron was leached from it (McFarlane, 1976, p. 57). The pallid zone is thought by McFarlane (1976) to form after laterite development, when incision of the soil pedon occurs by fluvial downcutting and groundwater moves later- 


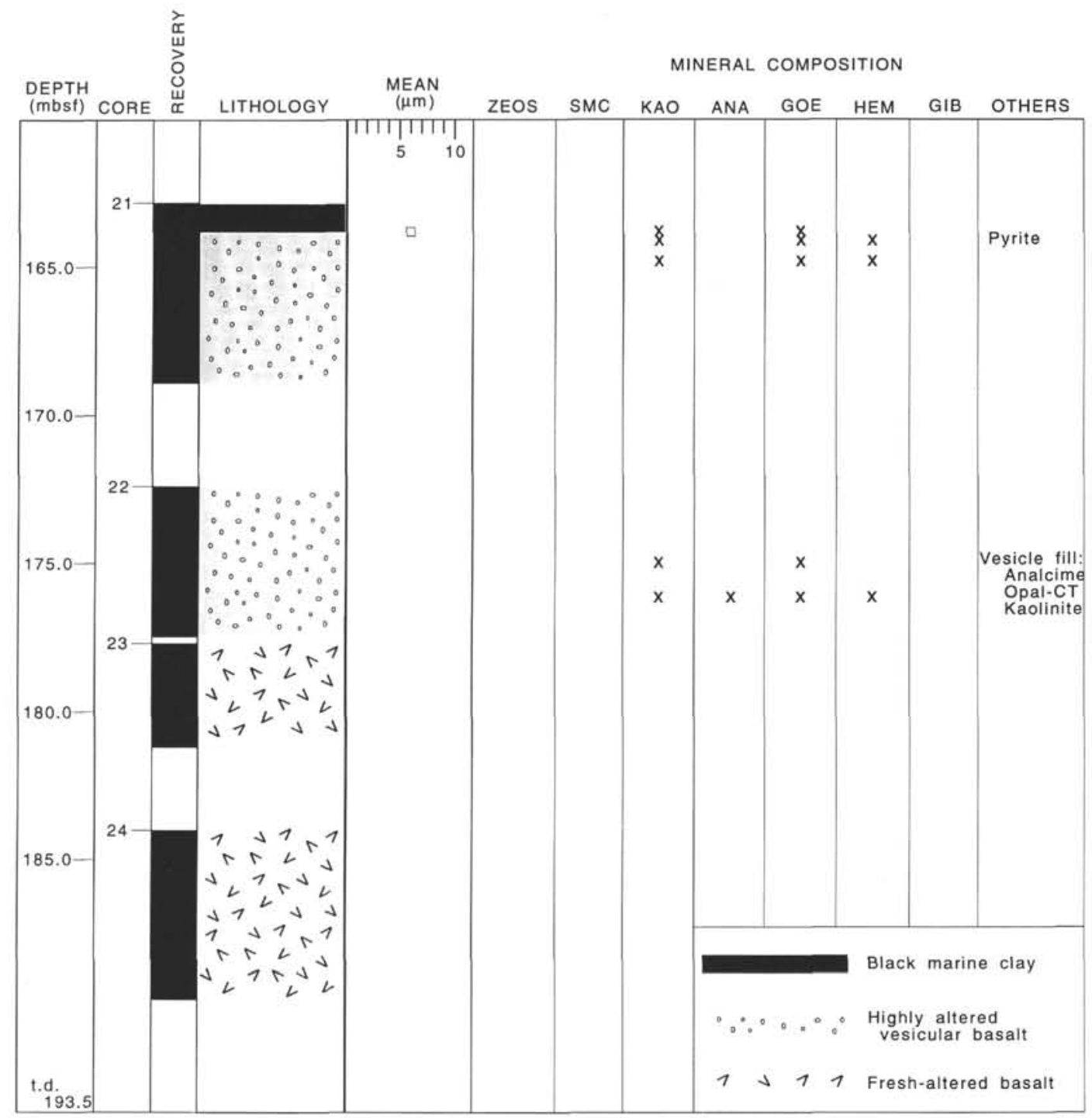

Figure 9. Stratigraphy, texture, and mineral composition of clay and enclosing deposits in Hole 874B, Wodejebato Guyot. For explanation of symbols and abbreviations, see Figure 1.

ally through the base of the profile and out of it into streams, carrying mobile ions with it.

Mottled zones and their occasional accompaniment, pallid zones, may occur anywhere from $30 \mathrm{~cm}$ below a soil surface to 3 or $4 \mathrm{~m}$ below the surface (Carroll, 1970; Kubiena, 1970; Mohr et al., 1972). The mottled zone may occur as a B or C horizon (Soil Survey Staff, 1975). It is impossible to place the mottled zone of Site 871 into either horizon because we do not know how much of the overlying soil was eroded when the island subsided to sea level. It may be that very little was actually eroded, and that much of the bioturbated, marineinfluenced sediment overlying it is simply reworked A horizon, making the mottled zone a B horizon. Alternatively, several meters may have been eroded, including one or more identifiable B horizons, making the mottled zone a $\mathrm{C}$ horizon. In most highly weathered soils with a mottled zone such as this, the mottled zone occurs so deeply that most pedologists are not concerned with it at all. Nevertheless, this feature is one that is found in deeply weathered soils, and so is considered a soil horizon, and evidence of subaerial weathering. This horizon could be classified as an oxic horizon, which is defined as a subsurface horizon that is not argillic (enriched in illuviated clay) or natric (enriched in evaporite minerals), is at least $30 \mathrm{~cm}$ thick, has no traces of weatherable primary silicate minerals or only traces; has $15 \%$ or more clay; has a cation exchange capacity (CEC) of 16 milliequivalents (meq) or less (although the CEC of the clays was not determined for this study, the CEC of kaolinite is about 5 meq; organic matter will increase this value); and has gradual or diffuse boundaries between subhorizons (Soil Survey Staff, 1975).

Variations in texture, especially resulting from clay translocation, are not significant features of oxic horizons. Eswaran et al. (1986) pointed out, after studying Oxisols in many places around the world, that clay translocation is not a significant process occurring in modern Oxisols. In Oxisols found on old surfaces today, little variation occurs in clay content, color, mineralogy, or micromorphology with depth (Eswaran et al., 1986).

\section{Site 873}

Unfortunately, the upper $4 \mathrm{~m}$ of clay was not recovered at Site 873 , as indicated by the logging results (Shipboard Scientific Party, $1993 \mathrm{c}$ ), but the massive red clay in Core $144-873 \mathrm{~A}-12 \mathrm{R}$ can be differentiated from the underlying, 0.6-m-thick, drab mottled interval and, beneath that, the reticulated clay interval. The upper, massive red clay fits the definition of an oxic horizon, as defined above. The underlying, drab mottled horizon was probably generated in watersaturated (hydromorphic) conditions. The reticulated material provides a transition from the basalt to the soil by preserving relict basalt 


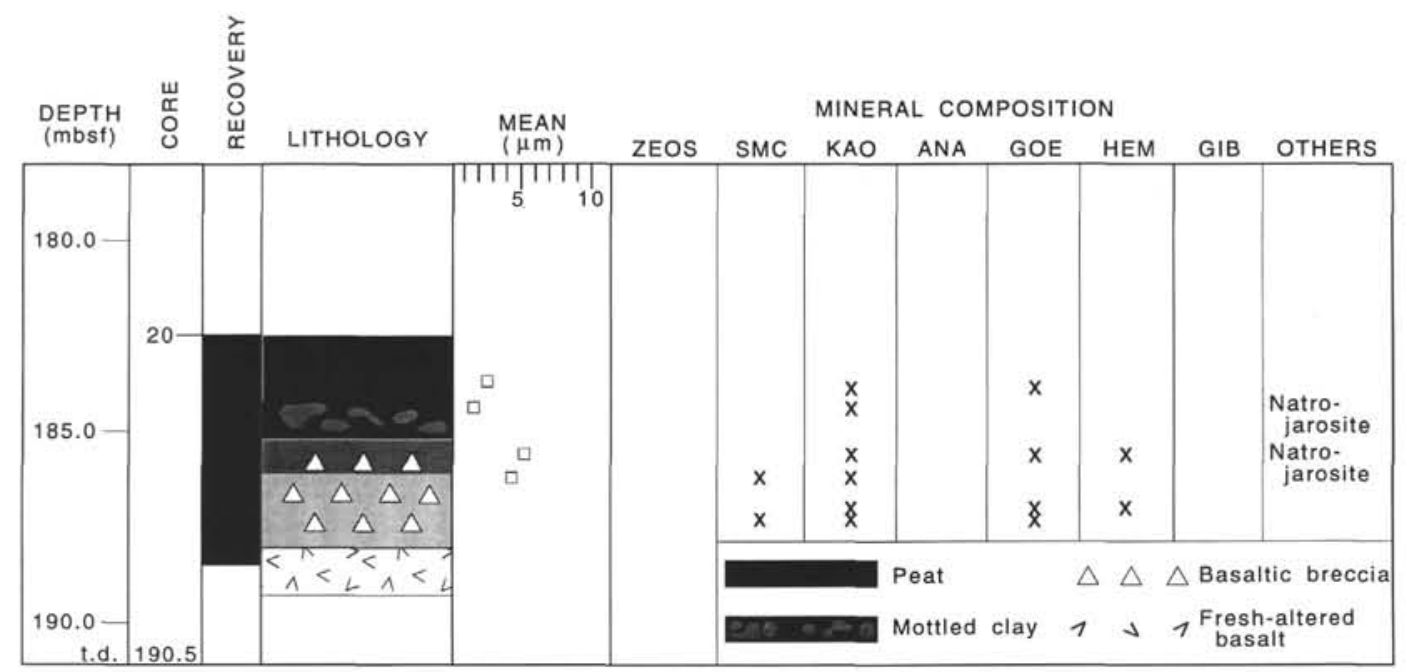

Figure 10. Stratigraphy, texture, and mineral composition of clay and enclosing deposits in Hole 877A, Wodejebato Guyot. For explanation of symbols and abbreviations, see Figure 1.

structure increasingly with depth (Pl. 1, Fig. 2; Pl. 3, Figs. 1-4). The reticulated patterns exhibit what may be the early stages of mottle development: iron has been translocated from the matrix into the veinlike structures (Pl. 3, Figs. 3, 4). With increased iron translocation, the centers of the polygons would become dominantly kaolinitic, like the gray and white mottles of Hole $871 \mathrm{C}$; the goethitic veins could become red or brown mottles, possibly depending on the local concentration of the minor, hematite-rich veins.

\section{Soil Structure: Ped Shape and Arrangement}

Nothing positively identifiable as peds, slickensides, cutans, or any feature that would delineate soil structure was observed in any of the clay units, but soil structure is commonly weakly developed or absent in extremely weathered soils (e.g., Soil Survey Staff, 1975). In addition, ped structure may be destroyed by burial compaction (Wright, 1992).

\section{Stratigraphic Position of the Clay Beds}

The principle argument for pedogenic origin of the clay units at all sites is the stratigraphic position: they all occur, with the exception of the clay at Site 878, above altered basalt and beneath marine deposits (Figs. 1, 6, 7, 9, 10, 12, 13). In addition, no marine fossils, including palynomorphs, are present throughout these clay units, except for the upper, marine, benthic-bioturbated interval in Hole 871C.

\section{Color}

The bright red colors of the clay units recovered during this leg could be developed by subterranean alteration, but the variation downward at Sites 871 (mottled to pallid to brown) and 873 (red to mottled to brown) suggests alteration and color development from the top downward (i.e., subaerially) at these sites. The color reversal at Sites 871,874 , and 877 (from gray and black at the top downward to an abrupt change to bright red) reflects a downward migration of a reducing front, behind which pyrite is abundant. (For a more detailed discussion of this Initial Transgressive Event, see Buchardt and Holmes, this volume.)

\section{"Destratification"}

The presence of relict basalt structure in the lowest parts of the clay units at Sites 871 and 873 , and throughout the clay units at Sites $872,874,877,878$, and 879 , indicates the absence of bioturbation by

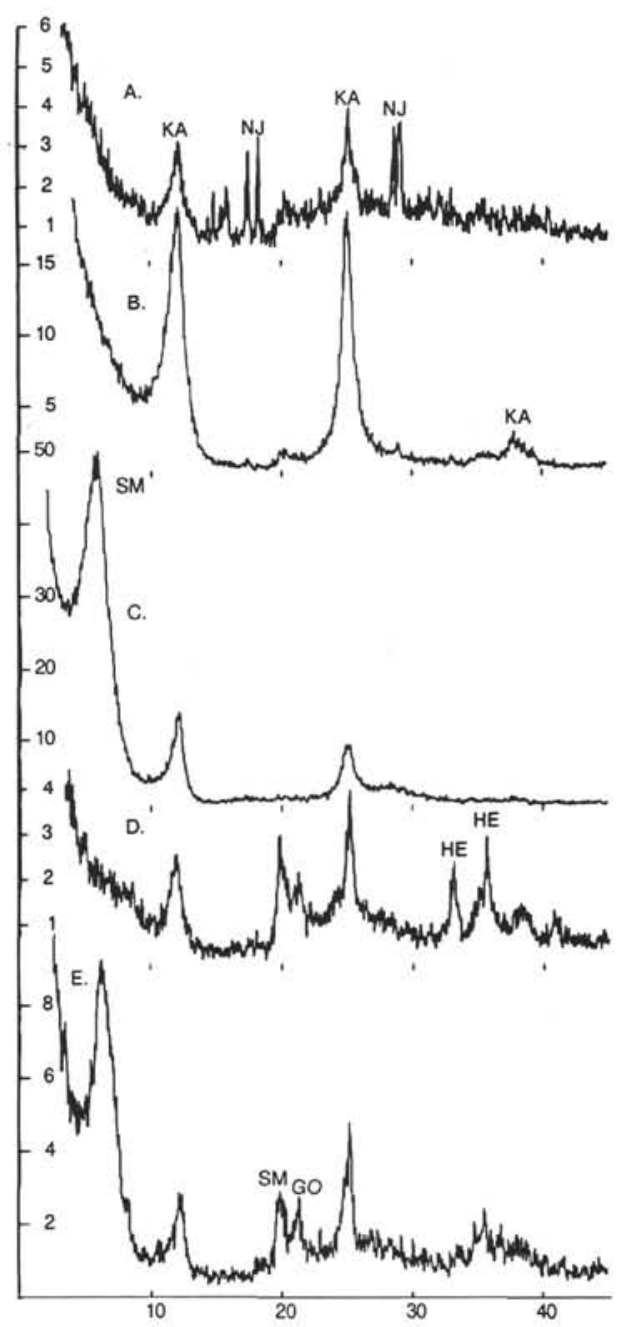

Figure 11. X-ray diffraction results from clay unit at Site 877. $Y$-axis is intensity, counts per second. $X$-axis is ${ }^{\circ} 2 \theta$, CuK $\alpha$ radiation. A. Sample 144877A-20R-2, 20-22 cm. Reduced zone with natrojarosite. B. Sample 144877A-20R-2, 139-141 cm, <2 $\mu \mathrm{m}$ fraction, reduced zone. C. Sample 144-877A-20R-3, 52-54 cm, $<2 \mu \mathrm{m}$ fraction, oxidized zone. D. Sample 144-877A-20R-3, 129-131 cm, bulk. E. Sample 144-877A-20R-4, 8-10 cm, bulk. $\mathrm{KA}=$ kaolinite, $\mathrm{NJ}=$ natrojarosite, $\mathrm{HE}=$ hematite, $\mathrm{SM}=$ smectite, and $\mathrm{GO}=$ goethite. 


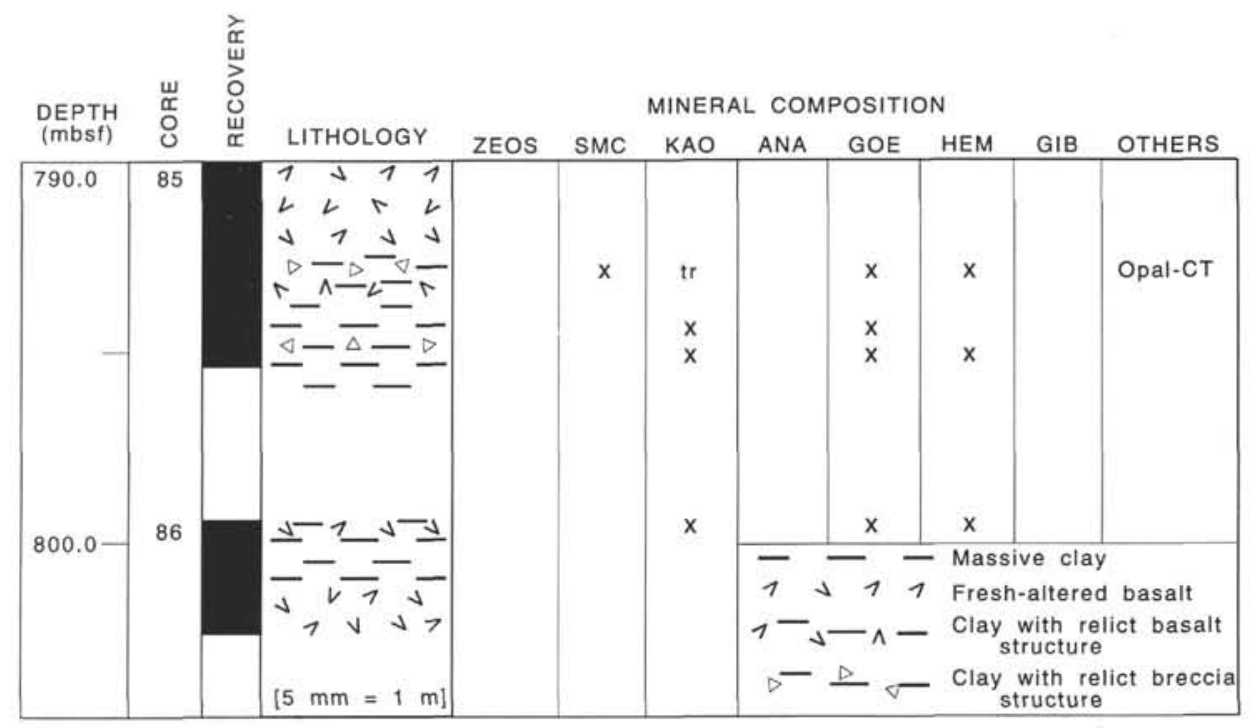

Figure 12. Stratigraphy and mineral composition of clay and enclosing units in Hole 878A, MIT Guyot. For explanation of symbols and abbreviations, see Figure 1.

terrestrial organisms. Root growth and soil fauna would cause material turnover and destruction of relict basalt structure. Such a stage of development occurs throughout the clay unit at Site 871 and in the upper $2 \mathrm{~m}$ of clay at Site 873 .

\section{Mineralogic and Chemical Variations}

The clay units from Sites 871,873 , and 877 all have only kaolinite (Al, Si) as a clay mineral in their upper parts (Figs. 1, 7, 10). Smectite ( $\mathrm{Mg}, \mathrm{Al}, \mathrm{Si}$ ) appears downhole at all three sites and becomes the only clay mineral in the deepest parts of these units. This downhole variation reflects the alteration of the parent basalt from the top down, as the more easily leached $\mathrm{Mg}$ is absent in the kaolinitic interval and present in the smectitic interval. At Site 874, the clay is kaolinitic throughout the sequence (Fig. 9). Only smectite is present in the upper clay unit of Site 878 . The clay mineral suite of the lower clay unit of Site 878 and the clay unit of Site 879 are variable downhole (Figs. 12, 13). Kaolinite is an abundant component of parts of the lower clay unit of Site 878 (Cores 144-878A-85R and -86R), but it is absent from the upper clay unit (Core 144-878A-80R), which suggests that the upper, laminated clay was derived from a less weathered terrane than the underlying unit.

In addition to clay minerals and iron oxide and oxyhydroxide, natroalunite and natrojarosite were observed in the clay units from Sites 871,873 , and 877 . Natroalunite occurs as a white mineral filling veins in the massive red clay (oxic horizon) of Site 873 (Figs. 8, 9). Although alunite is a common weathering product of sulfide minerals (Rodriquez-Clemente and Hidalgo-Lopez, 1985), its occurrence here is probably more analogous to that reported by Chitale and Güven (1987). They found natroalunite replacing kaolinite in the upper horizon of a paleosol developed over the Deccan Traps in the Kutch region of Gujarat State, India. The soil is thought to have developed during the Paleocene. In some areas, middle Eocene lignite and pyritic black shales were deposited over the laterites. Natroalunite probably formed in the buried paleosols by the weathering and oxidation of pyrite that generated acidic, sulfate-rich solutions. These leached into the underlying kaolinitic clay and mobilized aluminum (Chitale and Güven, 1987). Natrojarosite may have formed at Sites 871 and 877 by a similar mechanism: the oxidation of pyrite to form sulfate-rich, highly acidic waters that leached iron rather than aluminum, to form natrojarosite. The leachate of mine spoils is highly acidic, formed by the oxidation of pyrite. Brady et al. (1986) found that natrojarosite was the first mineral to precipitate in samples of water draining an acid mine spoil in southeastern Ohio. The $\mathrm{pH}$ level in this water was 2.9. Comparable acidic conditions might have occurred at these sites in the western Pacific. Why natroalunite or natrojarosite forms is unclear, but it is probably related to the relative abundance of $\mathrm{Fe}$ and $\mathrm{Al}$ in the respective profile.

It is significant that only a trace of gibbsite was observed in a single sample. This end member of the weathering series, smectite $\rightarrow$ kaolinite $\rightarrow$ gibbsite, is generally abundant in tropical soils. However, abundant gibbsite may form in alpine environments subject to high, seasonal rainfall in temperate zones (Reynolds, 1971). Gibbsite develops in soils in Hawaii that today are subject to at least $1 \mathrm{~m}$ of rainfall annually (Foote et al., 1972). Wollast (1967) suggested that high rates of potassium feldspar leaching favor gibbsite formation whereas lower rates promote kaolinite. The absence of gibbsite in these deeply weathered profiles may reflect the loss by erosion of surface horizons enriched in gibbsite; however, as gibbsite does occur in subsurface horizons, its absence more likely reflects drier climatic conditions for pedogenesis at these sites.

\section{Micromorphology}

No clay skins or sepic structure was visible in any thin sections from these clay units. The thin sections revealed diffuse boundaries among the mottles in the clay of Sites 871 and 873 .

\section{Evidence of Hydrothermal Alteration versus Pedogenesis}

Hydrothermal alteration of basalt can be interpreted from (1) the presence of calcite lining veins or filling vugs, (2) the delicate zoning of alteration minerals lining vugs and veins, and (3) the presence of high-temperature alteration minerals. Subaerial, low-temperature alteration (i.e., pedogenesis) is interpreted from (1) a more thorough alteration of the basalt to clays and iron and aluminum oxides, hydroxides, and oxyhydroxides; (2) the absence of delicate zoning of alteration minerals; (3) the presence of kaolinite as a significant component of the alteration paragenesis; and (4) the absence of moderate- to high-temperature (e.g., $>100^{\circ} \mathrm{C}$ ) alteration minerals, such as chlorite, celadonite, and zeolites. Kaolinite has not been reported as a hightemperature alteration product of basalts, although it is a common alteration product of more felsic parents, such as granites, quartz latites, and sedimentary rocks of the Suzhou kaolin deposits of China; rhyolite ignimbrites and andesitic-basaltic lavas of Sardinia; and rhyolitic tuffs and flows in Mexico and California (Murray, 1988). Hydrothermal kaolin in Japan is also the product of alteration of acidic to intermediate volcanic and pyroclastic rocks, and is found in association 


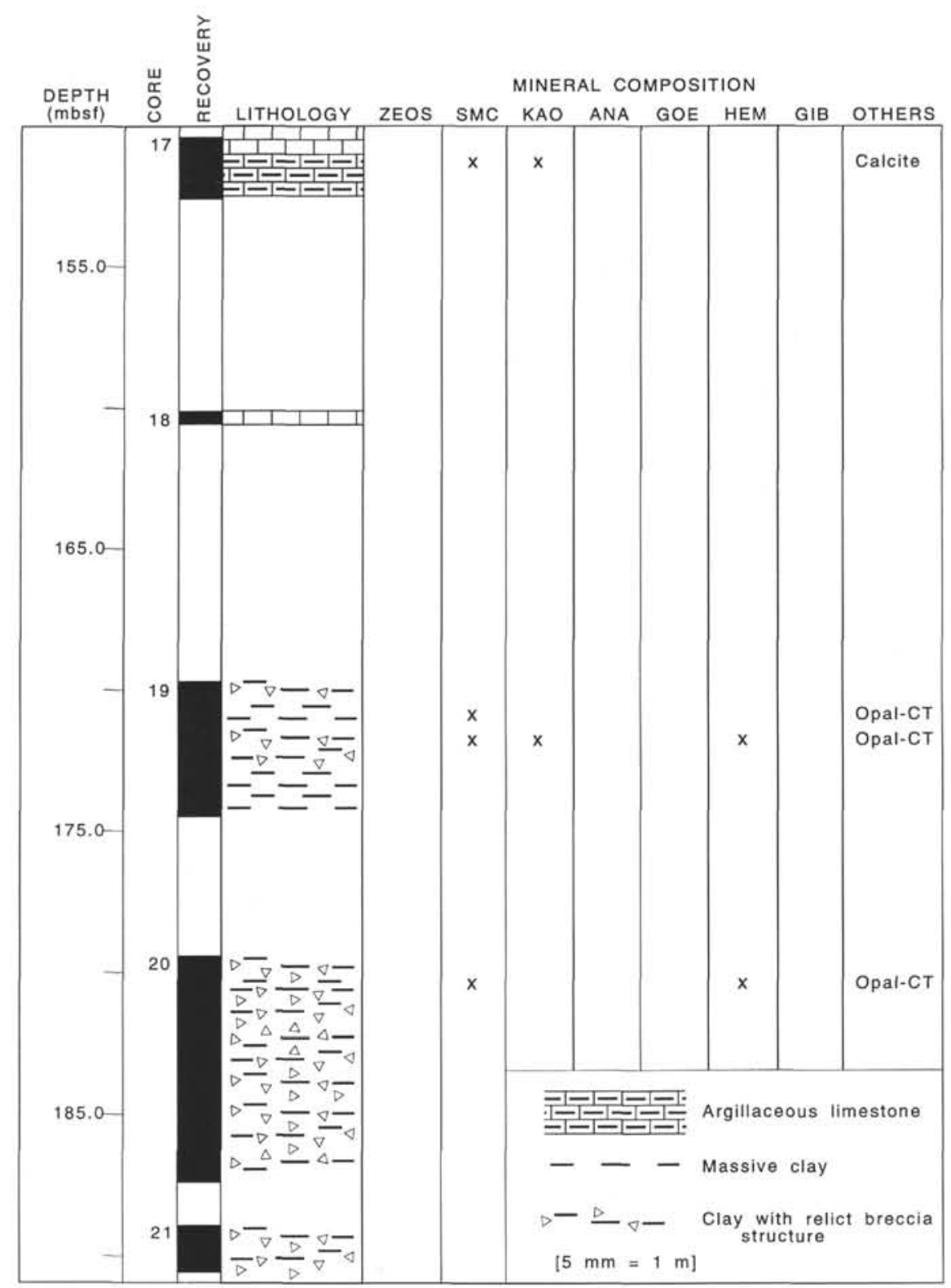

Figure 13. Stratigraphy and mineral composition of clay and enclosing units in Hole 879A, Takuyo-Daisan Guyot. For explanation of symbols and abbreviations, see Figure 1.

with gold and other metallic minerals (Nagasawa, 1978). Kaolinite is not reported as a hydrothermal alteration product of deep-sea basalts (e.g., Velde, 1985). Hydrothermal alteration is responsible for clay mineral development in soils developed in ash at the summit of Mauna Kea (Ugolini, 1974). At these high elevations, soils developed over glacigenic deposits are allophanic (containing only amorphous $\mathrm{Si}-\mathrm{Al}$ ), whereas those developed near areas of hydrothermal activity have crystalline smectite. But kaolinite is not present in these soils, again indicating that thick, kaolinitic clays do not develop by hydrothermal alteration of basalt.

Despite the absence of horizonation, mineral variation with depth, and the presence of relict basalt structure, the clay units of Sites 874 , 877 , and 879 probably formed by the subaerial weathering of basalt because of the pervasive occurrence of kaolinite. These units probably represent the basal, $\mathrm{C}$ horizons of the soils. It is an axiom among soil scientists that the C horizon "looks like rock, feels like soil." These clay units look like basalt, but are red and composed of kaolinitic clay.

Hydrothermal alteration may have generated the analcime found in the paleovesicles at Site 874. Analcime can form at surface tem- peratures, but generally is found only where $\mathrm{pH}$ is alkaline and pore waters (of soils or lake sediment) have been concentrated by evaporation in an arid climate (Gottardi and Galli, 1985). Where analcime is found in basalt fractures and vesicles, Gottardi and Galli (1985) state that it is usually assumed to have formed by hydrothermal alteration in the $100^{\circ}$ to $200^{\circ} \mathrm{C}$ range. In various hydrothermal fields in Iceland, analcime occurs in vesicles and fractures where the temperature exceeds $70^{\circ} \mathrm{C}$ (Kristmannsdóttir and Tómasson, 1978).

\section{The Landscape of Soil Development, Sites 871 and 873}

As mentioned above, thick mottled and pallid horizons (Site 871) can develop under lateritic conditions in upland soils (Mohr et al., 1972; McFarlane, 1976). The most common explanation for these is a widely fluctuating water table (e.g., Mohr et al., 1972; Carroll, 1970). However, as discussed above, McFarlane (1976) has proposed that these may form by a gradually subsiding water table and within a deflating land surface. The volcanic island begins to subside from the time it moves away from its hotspot source. If the altitude of the 
water table stays constant, this would provide a rising water table relative to subsiding land. The depth of weathering at Site 871 (28.6 $\mathrm{m}$ ) and the mature mineral assemblage (kaolinite, goethite, hematite) suggest a long period of volcanic quiescence. That is, this weathering occurred after volcanic activity ceased, while the island was subsiding. To get a lowering of the water table in a subsiding island, the Site 871 soil would have developed in an upland area with at least several tens of meters of elevation.

Deep lateritic profiles tend to develop on either stable, flat landscapes or at the base of upland areas, where they can thicken by downslope, colluvial processes (e.g., McFarlane, 1976; Eswaran et al., 1986; O'Connor et al., 1987; Spath, 1987). Similarly, very deep soils occur on the Hawaiian Islands in two areas: upland plateaus, where weathered horizons can be $50 \mathrm{~m}$ deep (Stearns, 1985); and lowland areas, which receive material by the erosion (colluvium, alluvium) of upland areas (Foote et al., 1972). In between these are steep areas where soils are thin because of high rates of erosion. Soils in the lowland areas are dominated by smectite because of the poor drainage and retention of basic cations, particularly $\mathrm{Mg}$. Soils in the upland plateau areas are dominated by kaolinite or gibbsite. Thus, thick, kaolinitic soils are characteristic of upland areas in the Hawaiian Islands, and the thick paleosol at Site 871 probably developed in such an upland area.

\section{How Long Did It Take These Soils to Form?}

Nahon (1990, p. 262) estimated that a kaolinitic saprolite differentiates at rates ranging from 4 to $40 \mathrm{~mm} / \mathrm{k}$.y., with basic rock weathering, on average, about 2.5 times faster than acidic. For Site 871, the 12.5$\mathrm{m}$-thick soil horizon (a minimum thickness considering that some of the soil was probably eroded during subsidence) would thus take 302,500 to 3,025,000 yr to form. Another estimate may be obtained by analogy to the soils now present on the Hawaiian Islands. Mottled zones are not mentioned in the state's soil surveys (Foote et al., 1972), but a plinthitic soil is described for the Island of Kauai, the oldest island for which a soil survey is available. This soil, the Kunuweia very gravelly clay loam $(0 \%-15 \%$ slopes) occurs near the highest elevations of the island $(3500-4000 \mathrm{ft}$, or $1100-1200 \mathrm{~m})$ and receives a current annual rainfall of 70-150 in. (1800-3800 mm). It is classified as a Plinthic Acrorthox, a typical Oxisol (orthox) exhibiting extreme weathering and bearing a plinthitic horizon, the B2ir (now Bs or Bv), which extends from 12 to $60 \mathrm{in}$. below the surface (Foote et al., 1972). Volcanic rocks on Kauai Island have been dated as 3.8 to $5.6 \mathrm{Ma}$ (compiled by Clague and Dalrymple, 1987). Stearns (1985) cites "radiometric measurements" of 1-2 Ma to develop a 50-m-thick weathered mantle in a well on the high plateau of Oahu (Leilehua Plateau, Wahiawa). The soils of the Big Island, Hawaii, are largely formed in ash and occur on fresh, undecomposed rock. The oldest flows on Big Island have been dated as less than $1 \mathrm{Ma}$ (Clague and Dalrymple, 1987). Therefore, 3 m.y. may not be an unreasonable estimate of the length of time it took for the soil horizon at Hole $871 \mathrm{C}$ to form.

\section{SUMMARY}

The clay recovered from Site 871 represents a subaerial weathering profile over the basalt. A possible reworked A horizon overlies a thick mottled zone, which in turn overlies a pallid zone. The complete weathered thickness, including highly weathered but recognizable basalt, is $28.6 \mathrm{~m}$. The thickness of the profile and the presence of the mottled and pallid horizons attest to a long period of subaerial weathering, probably beginning in an upland area at least several tens of meters above sea level. Natrojarosite has formed in the upper part, probably after submergence and deposition of organic-rich black, lagoonal mud.

Site 872 recovered only a few fragments of marine-influenced black mud. This material contains smectite and feldspar, indicating its derivation from a relatively fresh to moderately weathered terrane.

Site 873 comprises massive clay over a thin, drab mottled zone, which in turn overlies a highly reticulated claystone. The massive red clay is typical of many tropical soils and probably represents a pedogenic, oxic horizon. The drab color of the mottles over a thin zone attests to waterlogged conditions at the base of the profile during part of its development. The reticulated zone may represent "nascent mottling": iron has migrated to and concentrated in thick, goethitic veins, leaving a kaolinite-enriched polygon behind. The weathered horizon is approximately $23 \mathrm{~m}$ thick. The uniform oxic horizon might have formed in an upland or lowland area, but the drab-mottled subsurface horizon suggests a lowland or, at least, a poorly drained area.

The clay at Site 874 is the very base (C horizon) of a soil. It retains a relict parent basalt structure in the form of alteration mineral-filled vesicles that have a complex fill comprising kaolinite, opal-CT, and analcime. However, the matrix is completely altered to clay and comprises kaolinite, goethite, and hematite. Erosion of the surface horizon and possibly some of the subsurface horizon(s) was followed by deposition of organic-rich mud atop this zone. The ensuing reducing conditions lead to the diagenetic formation of natroalunite.

The clay at Site 877 is, like that of Site 874 , probably the base of a soil. The relict structure of an epiclastic volcanic deposit is still visible, but the material is completely altered to kaolinite and iron oxides and oxyhydroxides. Erosion of the surface horizon and underlying horizon(s) was followed by deposition of organic-rich muds. The contact of this reducing environment has moved downward into the formerly highly oxidizing soil profile and generated natrojarosite. Reducing conditions were probably not as intense as at Site 874 , as indicated by the mottling, interpreted here as bioturbation.

Two clay units recovered from Site 878 include an overlying, laminated, smectitic claystone and an underlying, complex claystone comprising kaolinite and smectite. A relict parent structure can be seen throughout most of the lower unit. It may be the base of a soil (C horizon), or it may have been altered by groundwater. Alternatively, this site may have undergone continued deposition by alluvial or colluvial processes that brought less mature, smectitic clay in the latter stages of development.

The clay recovered from Site 879 is similar to the lower unit of Site 878: it retains its parent structure throughout and has a variable mineral composition with depth. Again, this may represent only the deepest part of a weathering profile, alteration by groundwater, or, as the relict structure is that of a breccia, it may have formed by aggradational processes.

\section{CONCLUSIONS}

Basalt erupted to form these seamounts were mildly hydrothermally altered and then intensely weathered subaerially. Subaerial weathering, in its early stages, results in alteration of groundmass to smectite, goethite, and hematite followed by kaolinite and goethite. Intense weathering in a somewhat dry, subtropical to tropical environment has generated deeply weathered mantles, up to $30 \mathrm{~m}$ thick at Limalok Guyot, Site 871 . The weathering there was lateritic, producing a mottled zone overlying a pallid zone overlying degraded basalt. The mottling is less developed, even nascent, at Wodejebato Guyot, Site 873 . There, a reticulated zone shows migration of iron away from kaolinitic polygon centers and into thick brown "veins."

No positively identifiable surface horizons were recovered, although the brown clay of Site 873 probably represents the most near-surface part of any soil profile recovered during Leg 144 . Thick B horizons were recovered from Sites 871 and 873 , and only C horizons were recovered from Sites 877,878 , and 879 . These probably represent the deepest parts of eroded soil profiles and not "young" soils. The apparent variation in weathering among the sites, then, is largely a function of preservation of the soil profile.

It took a long time to develop the thick weathering mantle of Site 871 , considering published rates for the weathering of basalts as well as comparison to soil development on the Hawaiian Islands. This mantle probably represents no less than $1 \mathrm{~m} . \mathrm{y}$. of alteration, and possibly as much as $3 \mathrm{~m}$.y. 


\section{ACKNOWLEDGMENTS}

Many thanks to David Watkins and the Leg 144 co-chiefs, Drs. Janet Haggerty and Isabella Premoli Silva, for getting me involved in this interesting study. The former can hardly complain any more about "wish-she-was" igneous petrologists in the family. A special thanks to Drs. Hayden Murray, Janet Haggerty, Bjorn Buchardt, and an anonymous reviewer for helpful comments on the manuscript. Thanks to Kraig Heiden, Chris Rudnick, and Clayton Schnaze, who performed Sedigraph analyses and sample prep for the XRD work. Chris also made thin sections and helped with drafting and manuscript preparation. Diane Winter helped with sample preparation for SEM analyses.

\section{REFERENCES}

Bohn, H.L., McNeal, B.L., and O'Connor, G.A., 1985. Soil Chemistry (2nd ed.): New York (Wiley).

Brady, K.S., Bigham, J.M., Jaynes, W.F., and Logan, T.J., 1986. Influence of sulfate on Fe-oxide formation: comparisons with a stream receiving acid mine drainage. Clays Clay Miner., 34:266-274.

Carroll, D., 1970. Rock Weathering: New York (Plenum).

Chitale, D.V., and Güven, N., 1987. Natroalunite in a laterite profile over Deccan Trap basalts at Matanumad, Kutch, India. Clays Clay Miner., 35:196-202.

Clague, D.A., and Dalrymple, G.B., 1987. The Hawaiian-Emperor volcanic chain. Part I. Geologic evolution. In Decker, R.W., Wright, T.L., and Stauffer, P.H. (Eds.), Volcanism in Hawaii. Geol. Surv. Prof. Pap. U.S., 1350:5-54.

Drever, J.I., 1973. The preparation of oriented clay mineral specimens for $\mathrm{X}$-ray diffraction analysis by a filter-membrane peel technique. Am. Mineral., 58:553-554.

Eswaran, H., Ikawa, H., and Kimble, J.M., 1986. Oxisols of the world. Proc. Int. Symp. on Red Soils. Beijing (Science Press, Elsevier), 90-123.

Folk, R.L., 1980. Petrology of Sedimentary Rocks (2nd ed.): Austin, TX (Hemphill Publ.).

Foote, D.E., Hill, E.L., Nakamura, S., and Stephens, F., 1972. Soil Survey of the Islands of Kauai, Oahu, Maui, Molokai, and Lanai, State of Hawaii: Washington (U.S. Govt. Printing Office).

Gottardi, G., and Galli, E., 1985. Natural Zeolites: Berlin (Springer-Verlag).

Holmes, M.A., 1992. Cretaceous subtropical weathering followed by cooling at $60^{\circ}$ latitude: the mineral composition of southern Kerguelen Plateau sediment, Leg 120. In Wise, S.W., Jr., Schlich, R., et al., Proc. ODP, Sci. Results, 120: College Station, TX (Ocean Drilling Program), 99-111.

Jackson, M.L., 1969. Soil Chemical Analysis-Advanced Course (2nd ed): Madison, WI (M.L. Jackson), 27-95.

Kahrin, G.N., 1976. The petrology of magmatic rocks, DSDP Leg 38. In Talwani, M., Udintsev, G., et al., Init. Repts. DSDP, 38: Washington (U.S. Govt. Printing Office), 685-715.

Karpoff, A.M., 1980. The claystone layer between two basalt flows in Hole 432A: an argument for the emergence of Nintoku Seamount. In Jackson, E.D., Koizumi, I., et al., Init. Repts. DSDP, 55: Washington (U.S. Govt. Printing Office), 707-711.

Kristmannsdóttir, H., and Tómasson, J., 1978. Zeolite zones in geothermal areas in Iceland. In Sand, L.B., and Mumpton, F.A. (Eds.), Natural Zeolites: Occurrences, Properties, and Use: Oxford (Pergamon), 277-284.

Kubiena, W.L., 1970. Micromorphological Features of Soil Geography: New Brunswick, NJ (Rutgers Univ. Press).

Lewis, D.W., 1984. Practical Sedimentology: New York (Van Nostrand Reinhold), 80-100.

McFarlane, M.J., 1976. Laterite and Landscape: London (Academic Press).

Mohr, E.C.J., Van Baren, F.A., and Van Schuylenborgh, J., 1972. Tropical Soils: A Comprehensive Study of Their Genesis (3rd ed.): The Hague (Geuze Dordrecht).

Moore, D.M., and Reynolds, R.C., Jr., 1989. X-ray Diffraction and the Identification and Analysis of Clay Minerals: Oxford (Oxford University Press).

Murray, H.H., 1988. Kaolin minerals: their genesis and occurrences. In Bailey, S.W. (Ed.), Hydrous Phyllosilicates (Exclusive of Micas). Rev. Mineral., 19:67-89.

Nagasawa, K., 1978. Kaolin minerals. In Sudo, T., and Shimoda, S. (Eds.), Clays and Clay Minerals of Japan: Amsterdam (Elsevier), Dev. Sedimentol. Ser., 26:189-219.
Nahon, D.B., 1990. Introduction to the Petrology of Soils and Chemical Weathering: New York (Wiley).

Nilsen, T.H., and Kerr, D.R., 1978. Paleoclimatic and paleogeographic implications of a lower Tertiary laterite (latosol) on the Iceland-Faeroe Ridge, North Atlantic region. Geol. Mag., 115:153-182.

O'Connor, E.A., Pitfield, P.E.J., and Litherland, M., 1987. Landscape and Landsat over the eastern Bolivian Shield. In McFarlane, M.J. (Ed.), Laterites: Some Aspects of Current Research. Z. Geomorph. (Suppl.), 64:97-109.

Potter, P.E., Maynard, J.B., and Pryor, W.A., 1980. Sedimentology of Shale: New York (Springer-Verlag).

Premoli Silva, I., Haggerty, J., Rack, F., et al., 1993. Proc. ODP, Init. Repts., 144: College Station, TX (Ocean Drilling Program).

Retallack, G.J., 1988. Field recognition of paleosols. In Reinhardt, J., and Sigleo, W.R. (Eds.), Paleosols and Weathering Through Geologic Time: Principles and Applications. Spec. Pap.-Geol. Soc. Am., 216:1-20.

Reynolds, R.C., Jr., 1971. Clay mineral formation in an alpine environment. Clays Clay Miner., 19:361-374.

Rodriquez-Clemente, R., and Hidalgo-Lopez, A., 1985. Physical conditions in alunite precipitation as a secondary mineral. In Drever, J.I. (Ed.), The Chemistry of Weathering: Dordrecht (D. Reidel), 121-141.

Sager, W.W., Winterer, E.L., Firth, J.V, et al., 1993. Proc. ODP, Init. Repts., 143: College Station, TX (Ocean Drilling Program).

Shipboard Scientific Party, 1993a. Site 871. In Premoli Silva, I., Haggerty, J., Rack, F., et al., Proc. ODP, Init. Repts., 144: College Station, TX (Ocean Drilling Program), 41-103.

1993b. Site 872. In Premoli Silva, I., Haggerty, J., Rack, F., et al., Proc. ODP, Init. Repts., 144: College Station, TX (Ocean Drilling Program), 105-144.

, 1993c. Site 873. In Premoli Silva, I., Haggerty, J., Rack, F., et al., Proc. ODP, Init. Repts., 144: College Station, TX (Ocean Drilling Program), 145-207.

1993d. Site 874. In Premoli Silva, I., Haggerty, J., Rack, F., et al., Proc. ODP, Init. Repts., 144: College Station, TX (Ocean Drilling Program), 209-253.

, 1993e. Site 877. In Premoli Silva, I., Haggerty, J., Rack, F., et al., Proc. ODP, Init. Repts., 144: College Station, TX (Ocean Drilling Program), 287-312.

, 1993f. Site 878. In Premoli Silva, I., Haggerty, J., Rack, F., et al., Proc. ODP, Init. Repts., 144: College Station, TX (Ocean Drilling Program), 331-412.

1993g. Site 879. In Premoli Silva, I., Haggerty, J., Rack, F., et al., Proc. ODP, Init. Repts., 144: College Station, TX (Ocean Drilling Program), 413-441.

Singh, B., and Gilkes, R.J., 1991. Concentration of iron oxides from soil clays by $5 \mathrm{M} \mathrm{NaOH}$ treatment: the complete removal of sodalite and kaolin. Clay Miner, 26:463-472.

Soil Survey Staff, 1975. Soil Taxonomy: Washington (U. S. Govt. Printing Office). U.S. Department of Agriculture Handbook No. 436.

Spath, H., 1987. Landform development and laterites in northwestern Australia. In McFarlane, M.J. (Ed.), Laterites: Some Aspects of Current Research. Z. Geomorph. (Suppl.), 64:163-180.

Stearns, H.T., 1985. Geology of the State of Hawaii: Palo Alto, CA (Pacific Books).

Ugolini, F.C., 1974. Hydrothermal origin of the clays from the upper slopes of Mauna Kea, Hawaii. Clays Clay Miner., 22:189-194.

Velde, B., 1985. Clay Minerals: A Physico-Chemical Explanation of Their Occurrence: Amsterdam (Elsevier), Dev. Sedimentol. Ser., 40.

Wollast, R., 1967. Kinetics of the alteration of K-feldspar in buffered solutions at low temperature. Geochim. Cosmochim. Acta, 31:635.

Wright, V.P., 1992. Paleosol recognition: a guide to early diagenesis in terrestrial settings. In Wolf, K.H., and Chilingarian, G.V. (Eds.), Diagenesis, III: Amsterdam (Elsevier), Dev. Sedimentol. Ser., 47:591-619.

\footnotetext{
Abbreviations for names of organizations and publications in ODP reference lists follow the style given in Chemical Abstracts Service Source Index (published by American Chemical Society).
}

Date of initial receipt: 3 February 1994

Date of acceptance: 19 September 1994

Ms 144SR-038 

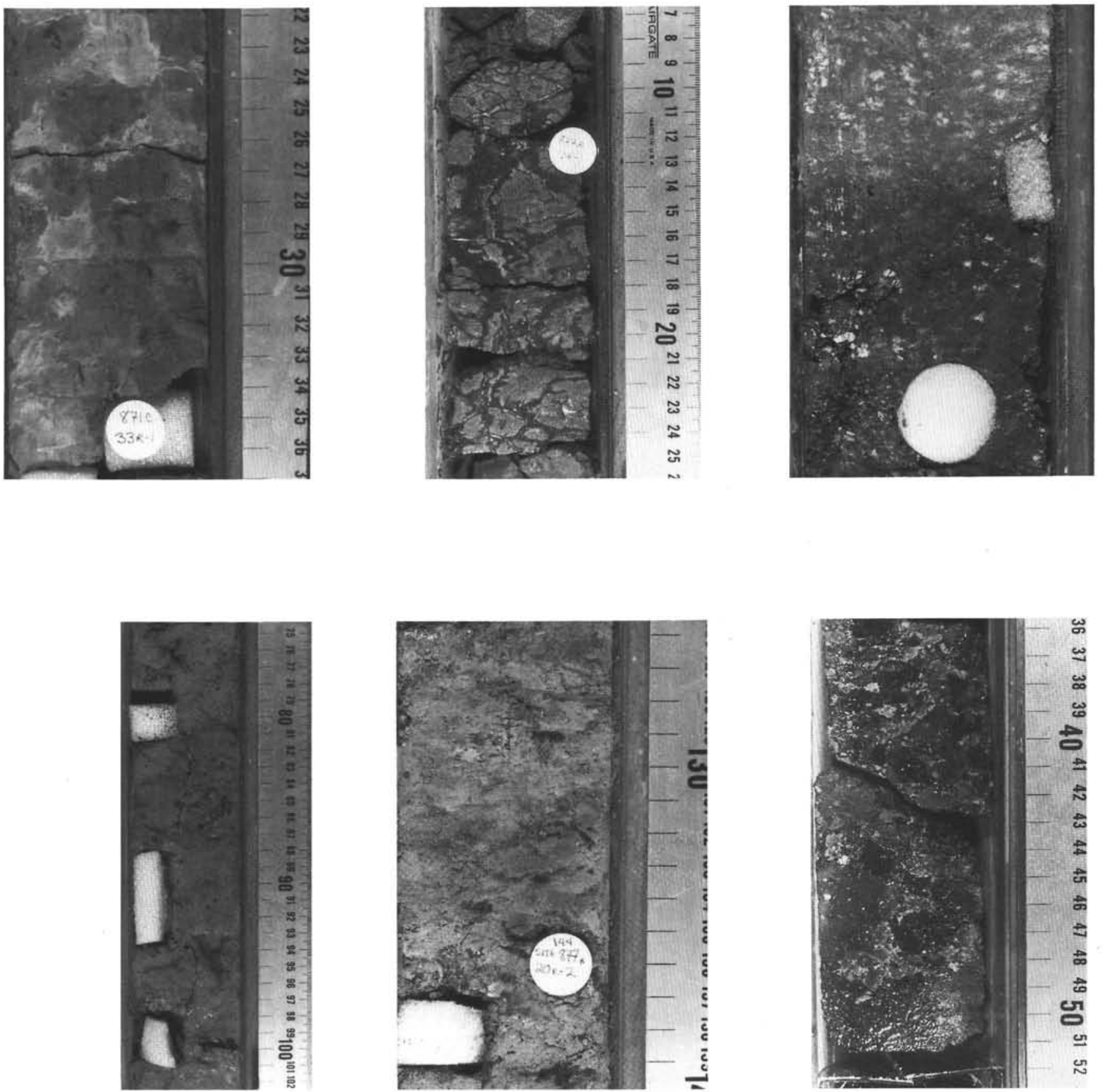

Plate 1. Photographs of cores taken during Leg 144. 1. Mottled zone of interval 144-871C-33R-1, 22-37 cm. Dark areas are brown, iron enriched, and may have iron glaebules or concretions at their centers. The lighter areas are the light gray colors. The gray areas in this photograph are a bright pink. 2. Reticulate pattern of clay unit in interval 144-873A-13R-1, 7-25 cm. The dark "veins" have increased concentrations of goethite and relict acicular plagioclase phenocryst microstructure (see Pl. 3, Figs. 1-3). The thin white (pink) "veins" in the center are dominantly kaolinite (see Pl. 3, Fig . 2). The centers of the polygons formed by the reticulate goethitic "veins" are dominantly kaolinite. In the upper part of the core, the polygon centers are massive and show no relict basalt structure (PI. 3, Figs. 1-3), but downcore they do contain relict plagioclase phenocrysts at the perimeter (Pl. 3, Fig. 4). 3. Redox boundary, interval 144-874B-21R-1, 121-134 $\mathrm{cm}$. The upper part is a light gray and enriched in pyrite. Below the boundary, the color is bright red and enriched in hematite. The only clay mineral in either zone is kaolinite. The white spots are "paleovesicles" of the parent basalt, now filled with kaolinite, opal-CT, and analcime (see Fig. 5B). 4. Mottled clay of interval 144-877A-20R-2, 74-103 cm. Mottles bifurcate upward $(80 \mathrm{~cm})$ as well as downward, indicating they are not roots or root haloes. They may be caused by bioturbation or by localized reducing conditions in a poorly drained soil. 5. Altered epiclastic volcanic deposit of interval 144-877A-20R-2, 125-140 cm. Relict parent structure such as this is not expected in any but a C horizon of a paleosol. 6. Altered epiclastic volcanic deposit of interval 144-879A-19R-1, $39-43 \mathrm{~cm}$. The matrix is entirely altered to smectite. Below this interval, kaolinite occurs and then disappears again. Nonsystematic variation of clay mineral composition with depth and the relict parent structure all suggest that this clay unit is not pedogenic, but possibly altered to its present state by groundwater. 

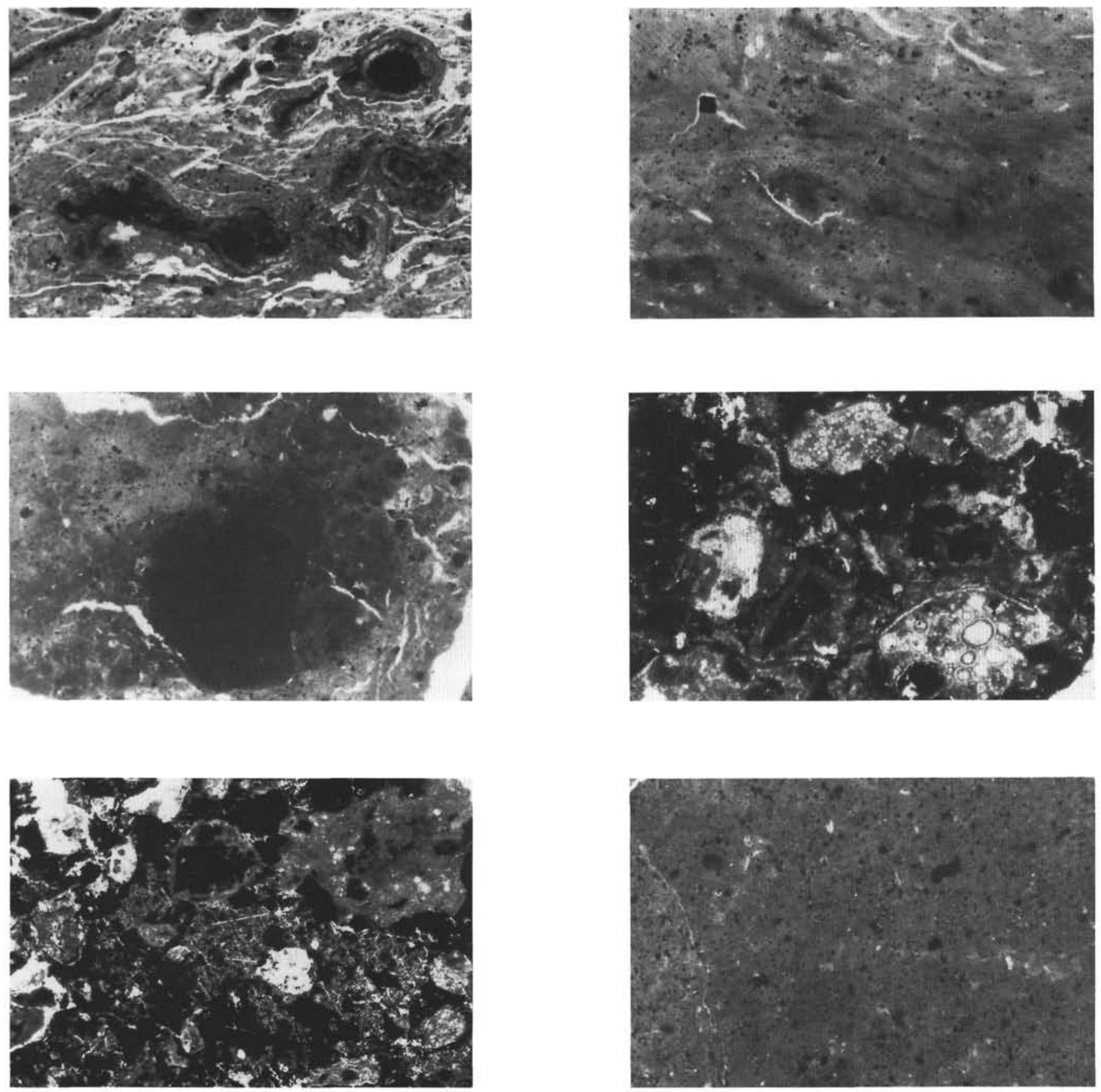

Plate 2. Photomicrographs of thin sections in plane polarized light of alteration minerals and pedogenic microstructures in altered/weathered basalts, Leg 144 . 1. Sample 144-871C-33R-1, 128-130 cm. Goethitic concretions, with concentric internal structure, form the loci of some of the brown mottles. Distance across photo is $4.1 \mathrm{~mm}$. 2. Sample 144-871C-32R-3, 126-128 cm. Black specks, composed of iron or carbon, are scattered through the upper part of the mottled clay and are probably hematite crystals or woody fragments. They are scattered through the matrix, regardless of mottle color. The mottles (seen here as various shades of gray) have diffuse boundaries. Distance across photo is $2.5 \mathrm{~mm}$. 3. Sample 144-871C-33R-1,34-36 cm. Goethitic glaebules, with no internal structure, form the loci of some of the brown mottles. Either concretions or glaebules may be found in the same sample. Distance across photo is $4.1 \mathrm{~mm}$. 4. Sample 144-871C-36R-2, 77-80 cm. Epiclastic volcanic deposit is composed of white or red, rounded to angular clayey pebbles. The white pebbles have an internal, concentric structure similar to that in kaolinized plagioclase phenocrysts (see Pl. 3, Figs. 5, 6). The black color in the photograph is hematitic cement that has permeated between and into clay pebbles. Distance across photo is $2.5 \mathrm{~mm}$. 5. Sample 144-871C-36R-2, 77-80 cm. Epiclastic volcanic deposit showing flow of pebbles as a result of burial compaction. Distance across photo is $6.8 \mathrm{~mm}$. 6. Sample 144-873A-12R-1, 75-77 cm. Massive microstructure of red, massive clay, probably an oxic horizon, with black specks composed of iron scattered throughout. Distance across photo is $2.5 \mathrm{~mm}$. 

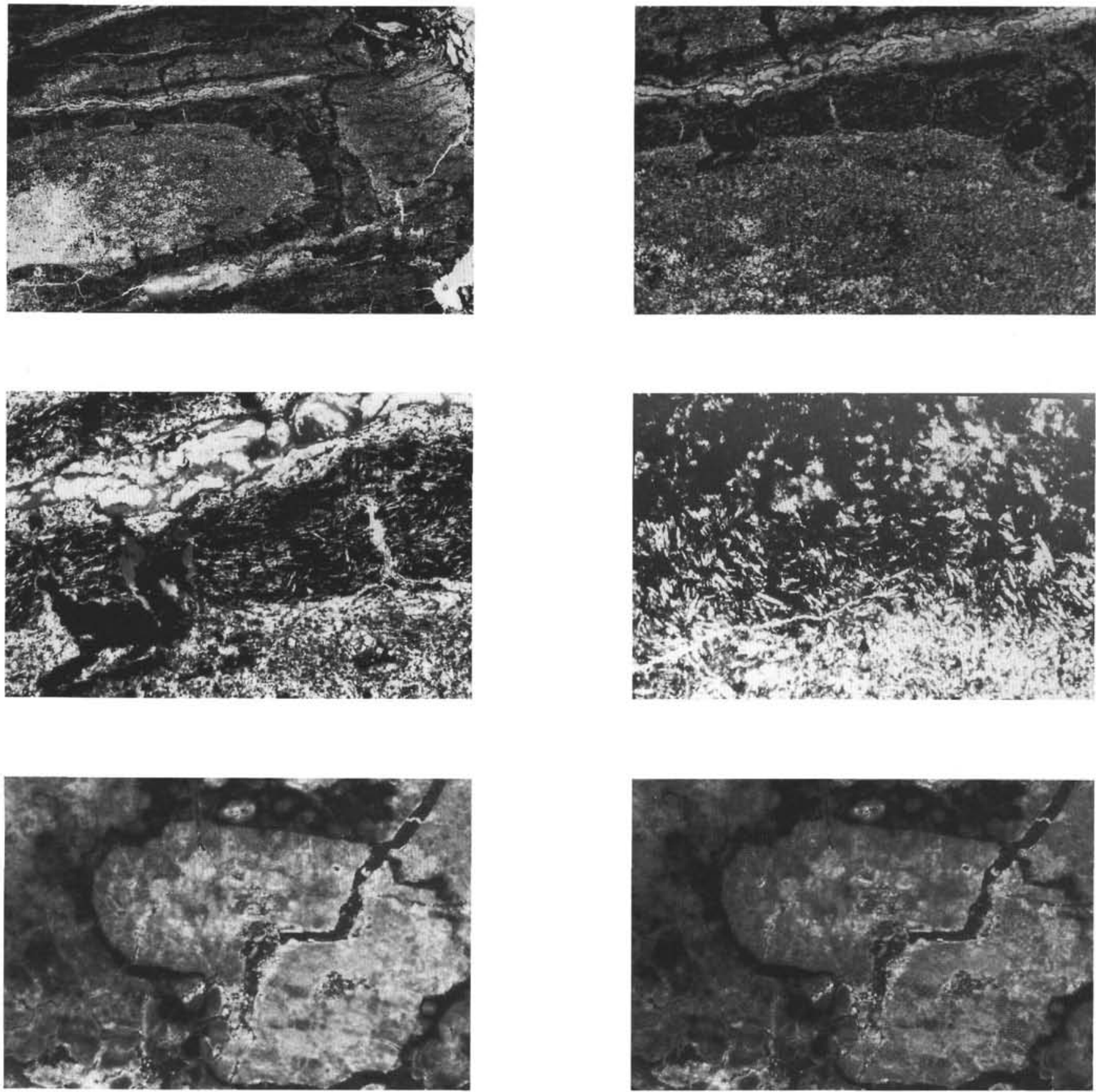

Plate 3. Photomicrographs of thin sections of alteration minerals and pedogenic microstructures in altered/weathered basalts, Leg 144. 1. Sample 144-873A12R-3, 9-12 cm. Plane polarized light. Reticulate pattern of lower part of clay unit (see Pl. 1, Fig. 2). Distance across photo is $17.5 \mathrm{~mm} .2$. Sample 144-873A-12R-3, 9-12 cm. Plane polarized light. Same sample as at left, but higher magnification showing goethitic cement concentrated along "veins" and authigenic (secondary or tertiary) kaolinite lining veins within the brown veins. Distance across photo is $6.8 \mathrm{~mm}$. 3. Sample 144-873A-12R-3, 9-12 cm. Plane polarized light. Same sample as above, but higher magnification, showing relict acicular plagioclase phenocrysts preserved in brown, goethitic veins, but not present in the central, kaolinized polygon. Distance across photo is $2.5 \mathrm{~mm}$. 4. Sample 144-873A-12R-4, 65-68 cm. Plane polarized light. Deeper in the profile, the centers of the polygons in the reticulated interval also retain relict acicular plagioclase phenocrysts at their periphery. Distance across photo is $2.5 \mathrm{~mm}$. $\mathbf{5}$. Sample 144-879A-21R-1, 67-70 cm. Crossed nicols. Relict plagioclase feldspar phenocryst in clay, completely kaolinized and showing concentric pattern of kaolinite crystals. This sort of alteration may have generated the white pebbles of the epiclastic volcanic deposit at Site 871 (see Pl. 2, Fig. 4). Note relict cleavage. Distance across photo is $6.8 \mathrm{~mm}$. 6. Sample 144-879A-21R-1, 67-70 cm. Reflected light. Same sample as at left but reflected light reveals that cleavage patterns are not an artifact of sample preparation. Distance across photo is $6.8 \mathrm{~mm}$. 